\title{
Insulin signalling mechanisms for triacylglycerol storage
}

\author{
M. P. Czech • M. Tencerova • D. J. Pedersen • M. Aouadi
}

Received: 23 October 2012 / Accepted: 22 January 2013 /Published online: 27 February 2013

(C) Springer-Verlag Berlin Heidelberg 2013

\begin{abstract}
Insulin signalling is uniquely required for storing energy as fat in humans. While de novo synthesis of fatty acids and triacylglycerol occurs mostly in liver, adipose tissue is the primary site for triacylglycerol storage. Insulin signalling mechanisms in adipose tissue that stimulate hydrolysis of circulating triacylglycerol, uptake of the released fatty acids and their conversion to triacylglycerol are poorly understood. New findings include (1) activation of DNAdependent protein kinase to stimulate upstream stimulatory factor (USF)1/USF2 heterodimers, enhancing the lipogenic transcription factor sterol regulatory element binding protein 1c (SREBP1c); (2) stimulation of fatty acid synthase through AMP kinase modulation; (3) mobilisation of lipid droplet proteins to promote retention of triacylglycerol; and (4) upregulation of a novel carbohydrate response element binding protein $\beta$ isoform that potently stimulates transcription of lipogenic enzymes. Additionally, insulin signalling through mammalian target of rapamycin to activate transcription and processing of SREBP1c described in liver may apply to adipose tissue. Paradoxically, insulin resistance in obesity and type 2 diabetes is associated with increased triacylglycerol synthesis in liver, while it is decreased in adipose tissue. This and other mysteries about insulin signalling and insulin resistance in adipose tissue make this topic especially fertile for future research.
\end{abstract}

Keywords Adipose $\cdot$ Fatty acids $\cdot$ Insulin resistance $\cdot$ Lipogenesis $\cdot$ Lipolysis $\cdot$ Obesity $\cdot$ Review $\cdot$ Triacylglycerol

M. P. Czech $(\varangle) \cdot$ M. Tencerova $\cdot$ D. J. Pedersen $\cdot$ M. Aouadi Program in Molecular Medicine, University of Massachusetts Medical School, 373 Plantation Street,

Worcester, MA 01605, USA

e-mail: Michael.Czech@umassmed.edu

$\begin{array}{ll}\text { Abbreviations } \\ \text { ACC } & \text { Acetyl-CoA carboxylase } \\ \text { AMPK } & \text { AMP-activated protein kinase } \\ \text { ATGL } & \text { Adipose tissue triglyceride lipase } \\ \text { CGI-58 } & \text { Comparative gene identification-58 } \\ \text { ChREBP } & \text { Carbohydrate response element-binding protein } \\ \text { DAG } & \text { Diacylglycerol } \\ \text { DNA- } & \text { DNA-dependent protein kinase } \\ \text { PK } & \\ \text { FAS } & \text { Fatty acid synthase } \\ \text { FATP1 } & \text { Fatty acid transporter protein 1 } \\ \text { FSP27 } & \text { Fat-specific protein of 27 kDa } \\ \text { HFD } & \text { High-fat diet } \\ \text { HSL } & \text { Hormone-sensitive lipase } \\ \text { LPL } & \text { Lipoprotein lipase } \\ \text { MAPK } & \text { Mitogen-activated protein kinase } \\ \text { mTOR } & \text { Mammalian target of rapamycin } \\ \text { mTORC } & \text { Mammalian target of rapamycin complex } \\ \text { NP } & \text { Natriuretic peptide } \\ \text { PI3K } & \text { Phosphatidylinositol 3-kinase } \\ \text { PKA } & \text { Protein kinase A } \\ \text { PKC } & \text { Protein kinase C } \\ \text { PKG } & \text { Protein kinase G } \\ \text { PPAR } & \text { Peroxisome proliferator-activated receptor } \\ \text { SOCS } & \text { Suppressor of cytokine signalling proteins } \\ \text { SREBP } & \text { Sterol regulatory element binding protein } \\ \text { S6K } & \text { S6 kinase } \\ \text { Th } & \text { T helper } \\ \text { USF } & \text { Upstream stimulatory factor } \\ & \end{array}$

\section{Introduction}

Insulin signalling and its impairment in obesity and type 2 diabetes is a vast field that commands the full attention of 
many hundreds of laboratories worldwide. Scientific output has been extremely prolific, making it unlikely that any investigator has actually read all the relevant literature, which includes 25,082 publications listed in PubMed under the topic 'insulin signaling' and 67,013 papers listed under the heading 'insulin resistance'. Review articles that discuss insulin resistance number 15,711, as of August 2012. Also, for many of the most interesting findings, separating fact from fiction will take years for confirmatory studies to be reported and controversies resolved. These realities create a huge challenge for scientists trying to understand insulin signalling mechanisms and their dysfunctions in metabolic disease, especially for those who are now just entering the field.

One approach to this scientific challenge is to focus on a small but critical corner of the puzzle. Such a niche area in the study of insulin signalling is lipid storage, dramatically highlighted in the images of the first diabetic patients treated with insulin in 1922, who were transformed from emaciated to plump within a few weeks [1]. At the cellular and molecular levels, insulin's actions indeed coordinately enhance the synthesis of triacylglycerol, the central currency of stored lipid in humans. While hepatocytes are a principal site of de novo lipogenesis (synthesis of fatty acid) as well as overall lipogenesis (esterification of fatty acid with glycerol 3-phosphate to form triacylglycerol) [2], adipocytes are the principal site of triacylglycerol storage in healthy individuals [3]. Importantly, deficits in adipocyte capacity for increasing triacylglycerol deposition, for example in human lipodystrophies and obesity, contribute to systemic lipid overload and 'lipotoxicity', which in turn are thought to disrupt whole body glucose tolerance [4]. Thus, we focus in this review on insulin signalling and its dysfunctions specifically in relation to adipocyte triacylglycerol sequestration, recognising this topic's broader implications for understanding the pathophysiology of obesity and type 2 diabetes.

\section{Adipose lipid storage capacity modulates systemic insulin sensitivity}

Increased circulating fatty acids and triacylglycerol are strongly correlated with impaired insulin signalling and glucose intolerance in obesity and type 2 diabetes [5, 6]. Indeed, dysfunctional lipid metabolism has been highlighted as the primary defect in the aetiology of metabolic disease [7]. Furthermore, the accumulation of fat in non-adipose tissue (e.g. liver and muscle) has been described as a strong predictor of type 2 diabetes mellitus, although the molecular mechanisms by which lipids contribute to insulin resistance in these tissues is still unclear (for review, see [8, 9]). Systemic insulin resistance includes impaired suppression of hepatic gluconeogenesis by insulin and attenuated insulin stimulation of skeletal muscle and adipocyte glucose uptake.
Inducing hypertriacylglycerolaemia or high circulating NEFA levels in human volunteers using lipid emulsion infusions can cause systemic insulin resistance as measured by hyperinsulinaemic clamps [10-13]. In addition, incubating cells with high concentrations of lipids, primarily palmitate, demonstrates negative effects of increased circulating lipids on insulin action in peripheral tissues [14-16]. However, a contrary viewpoint is that circulating NEFA levels are minimally elevated in human obesity, and more work is required in this area [17].

Evidence that adipose triacylglycerol storage capacity is a critical factor in elevated circulating triacylglycerol and insulin resistance is provided by experimentally promoting adipogenesis in mice [18, 19], which improves systemic insulin sensitivity. This likely occurs in part through sequestration of lipid away from other insulin target tissues, as well as by providing beneficial adipokines [20-22]. Specifically promoting adipocyte triacylglycerol synthesis in transgenic mice through increasing levels of critical lipogenic enzymes in adipocytes, exemplified by acyl-CoA:diacylglycerol acyltransferase [20], indeed produces increased adiposity but also improves glucose tolerance. Furthermore, promoting adipose glucose uptake and lipogenesis by transgenic enhancement of glucose transporter 4 (GLUT4) levels reverses diabetes in mice [21,23].

\section{Insulin signalling mechanisms to attenuate adipocyte lipolysis}

Insulin signalling enhances lipid storage in adipocytes by both stimulating triacylglycerol synthesis and inhibiting its breakdown. Triacylglycerol is stored in lipid droplets, which also contain lipid droplet proteins, including perilipin 1, adipophilin/adipocyte differentiation-related protein, tailinteracting protein of $47 \mathrm{kDa}$ and fat-specific protein of $27 \mathrm{kDa}$ (FSP27)/Cidec [24-27]. Active hydrolysis of stored triacylglycerol into its constituent fatty acids and glycerol occurs in starvation and exercise, through the actions of lipases and their regulators localised on the droplets (Fig. 1). Three key lipases control lipolysis: adipose tissue triglyceride lipase (ATGL) primarily catalyses triacylglycerol into diacylglycerol (DAG), hormone-sensitive lipase (HSL) has a higher affinity toward DAG than triacylglycerol, and monoacylglycerol lipase completes the last step in the process [28-31]. Two lipolytic pathways are highlighted in Fig. 1. The most studied pathway involves $\beta$-adrenergic stimulation by catecholamines, leading to increased cAMP levels and protein kinase A (PKA) activation, which increases access of lipases to the triacylglycerol droplet. In the fed state, perilipin binds the ATGL co-activator known as comparative gene identification-58 (CGI-58). Upon activation, PKA phosphorylates perilipin 1, releasing CGI-58 to activate ATGL $[32,33]$. 
(a)

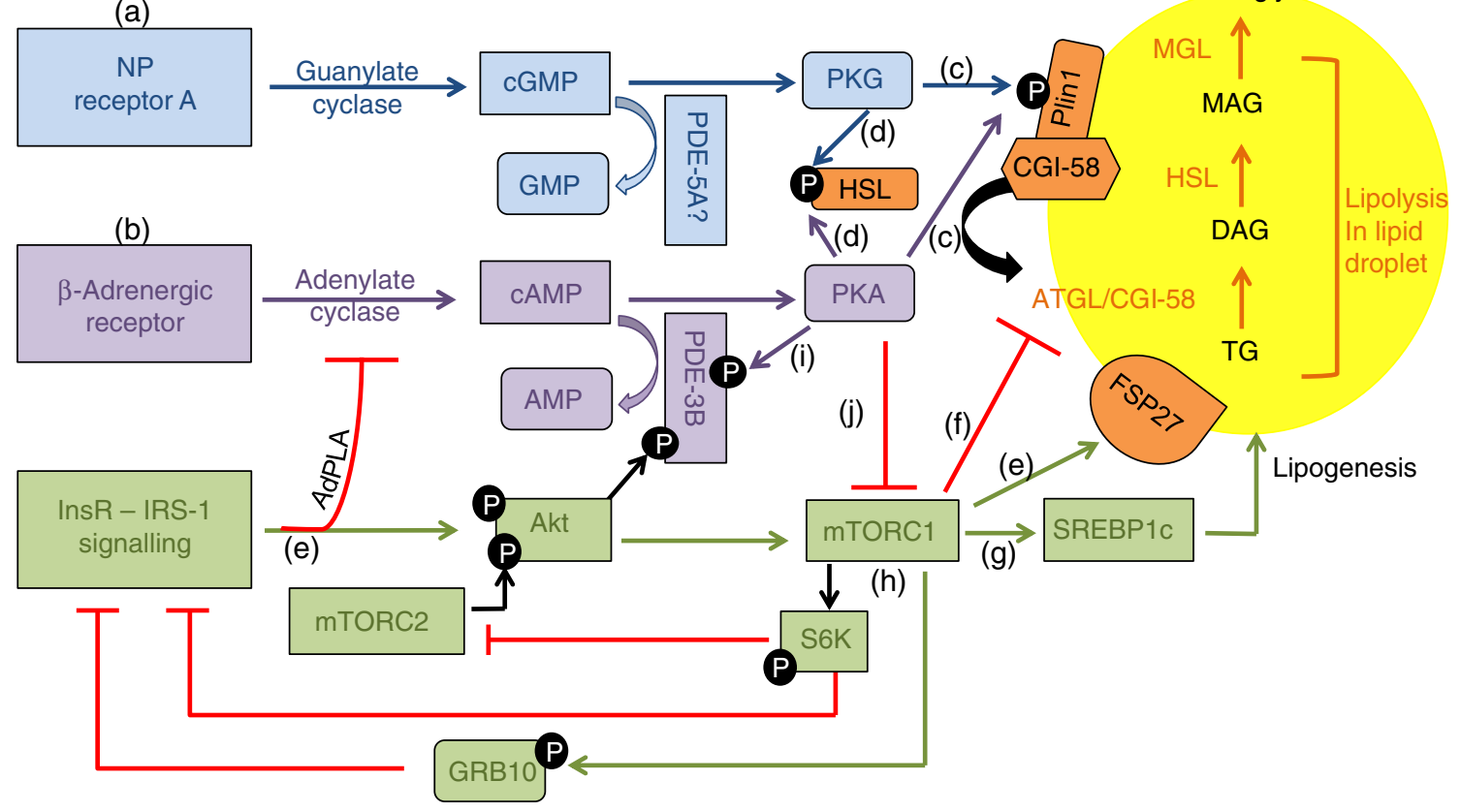

Fig. 1 Insulin signalling attenuates cAMP-mediated lipolysis at multiple steps in adipocytes. (a) NPs signal through NP receptor A to increase cGMP levels and activate PKG. (b) Stimulation of the $\beta$ adrenergic receptor increases cAMP levels, which activates PKA. (c) The lipolytic actions of PKA and PKG converge through phosphorylating perilipin 1 (Plin1), releasing CGI-58 to bind and activate ATGL, thereby stimulating hydrolysis of triacylglycerol (TG) to DAG. (d) Both PKA and PKG also phosphorylate HSL, inducing its translocation to lipid droplets, where it interacts with phosphorylated perilipin and acts primarily to convert DAG to monoacylglycerol (MAG). (e) Activation of the insulin receptor (InsR-IRS signalling pathway inhibits lipolysis through activation of adipose-specific phospholipase $\mathrm{A}_{2}\left(\mathrm{AdPLA}_{2}\right)$,

In contrast, HSL activation arises through direct phosphorylation by PKA on multiple residues, inducing HSL translocation to the lipid droplet surface via interaction with the $\mathrm{NH}_{2}$ terminal of phosphorylated perilipin-1. This coordinated activation of both HSL and ATGL results in a powerful lipolytic stimulation [34, 35].

A second lipolytic pathway depicted in Fig. 1 is stimulated by natriuretic peptide (NP). A recent study demonstrated that this pathway is activated following cold exposure, increasing the thermogenic activity of white adipose tissue via a p38 mitogen-activated protein kinase (MAPK)-dependent pathway [36]. Binding of NPs to the active A isoform of the NP receptor results in increased cGMP levels and activation of protein kinase $\mathrm{G}(\mathrm{PKG})$, which phosphorylates the same targets as PKA, namely HSL and perilipin 1, independently of $\beta$-adrenergic stimulation [37-39]. Its role in enhancing adipose tissue thermogenesis, together with the fact that it is downregulated in obesity $[36,40]$, makes this NP receptor A signalling pathway a potential therapeutic target.

Insulin's potent inhibition of lipolysis not only favours lipid storage but also markedly decreases circulating fatty which inhibits adenylate cyclase via prostaglandin $\mathrm{E}_{2}$ synthesis, while activation of Akt leads to phosphodiesterase 3B (PDE-3B) activation to lower cAMP levels. Lipid droplet protein FSP27 is also upregulated by insulin signalling. (f) mTORC1 acts as a critical node in the control of adipocyte lipid metabolism, through reducing Atgl mRNA levels and (g) stimulating lipogenesis via SREBP1-c. Alternatively, mTORC1 stimulates a negative feedback loop through activation of (h) S6K and growth factor receptor-bound protein 10 (GRB10). (i) PKA can also regulate adipocyte lipid handling by modulating its own activity by phosphorylating and activating PDE-3B, while PKA has also been shown to $(\mathbf{j})$ inhibit mTORC1. MGL, monoacylglycerol lipase

acid levels. Insulin signalling is initiated through its receptor tyrosine kinase, which phosphorylates insulin receptor proteins (IRS) leading to phosphatidylinositol 3-kinase activation (PI3K), phosphatidylinositol 3,4,5-triphosphate generation and Akt activation (see [41, 42] for comprehensive reviews). This signalling markedly inhibits PKA- but not PKG-mediated lipolysis. At least four sites of negative regulation by insulin signalling can be identified on the $\beta$-adrenergic receptor-mediated lipolytic pathway (Fig. 1). First, insulin inhibits lipolysis through phosphorylation of adipose-specific phospholipase $A_{2}$, which via arachidonic acid production increases prostaglandin $\mathrm{E}_{2}$ levels and in a paracrine/autocrine manner reduces cAMP levels through inhibition of adenylate cyclase [43, 44]. The exact mechanism of this pathway remains to be elucidated. Second, activation of Akt phosphorylates and activates phosphodiesterase, thereby reducing cAMP levels and PKA activity [45-47]. Third, the downstream target of Akt, mammalian target of rapamycin complex 1 (mTORC1), attenuates $\beta$-adrenergic stimulated lipolysis through inhibiting ATGL mRNA levels, while mTORC1 itself is inhibited by PKA 
[48]. Fourth, insulin upregulates the levels of the lipid droplet protein FSP27 through increasing its transcription, which dampens lipolysis [27, 49]. Thus, insulin action to inhibit lipolysis in this multifaceted mode provides a powerful restraint on the release of fatty acids from triacylglycerol within adipocyte lipid droplets.

\section{Rapid insulin signalling mechanisms stimulate adipocyte lipogenesis}

The actions of insulin to stimulate synthesis of triacylglycerol in adipocytes can be divided into two categories based on the time frame of their stimulatory effects. A summary of rapid insulin effects that occur within minutes to an hour or two is presented in Fig. 2. The major acute insulin effect is a severalfold stimulation of glucose transport into cells, mediated by increased translocation of GLUT4 to the plasma membrane through signalling by PI3K [50-54]. In adipocytes, this stimulation of glucose entry (Fig. 2) acts in concert with the process of glyceroneogenesis, [55] to provide intracellular substrate for synthesis of glycerol 3-phosphate needed for esterification of fatty acids into triacylglycerol. It is important to note that the process of glyceroneogenesis, whereby pyruvate is converted to glycerol 3-phosphate, can be the major contributor to this esterification step as well, and is discussed in detail elsewhere [55]. The signals downstream of insulinstimulated PI3K may include atypical protein kinase C (PKC) isoforms [56, 57], but it seems that the predominant signals derive from Akt activation [58, 59]. The RabGAP (Rab GTPase-activating protein) AS160/ TCB1D4 has been identified as an Akt substrate that regulates GLUT4 translocation [60-62], but studies on manipulating AS160 levels suggest that other, as yet unidentified, Akt substrates are also involved $[63,64]$. In spite of decades of work, the detailed mechanisms of insulin stimulation of glucose transport remain largely unresolved.

Two pathways stimulated by insulin contribute to the pool of fatty acids that is esterified into triacylglycerol in adipocytes: fatty acid uptake from circulating triacylglycerol and de novo fatty acid synthesis. The former is the major pathway and is mediated in part through insulin stimulation of mRNA and protein levels of lipoprotein lipase (LPL), as well as the activity of LPL, which hydrolyses circulating triacylglycerols in lipoproteins into glycerol and fatty acids (Fig. 2) [65, 66]. Adipocyte-derived LPL is required for efficient fatty acid uptake and storage [67], and insulin infusion in humans increases adipose tissue LPL activity within a few hours [68, 69]. LPL activity is modulated through both post-transcriptional and post-translational mechanisms [66, 70]. In isolated rat adipocytes, inhibition of PI3K completely blocks the stimulation of LPL activity by insulin, while inhibition of mTOR partially inhibits insulin-stimulated LPL activity [71]. Fatty

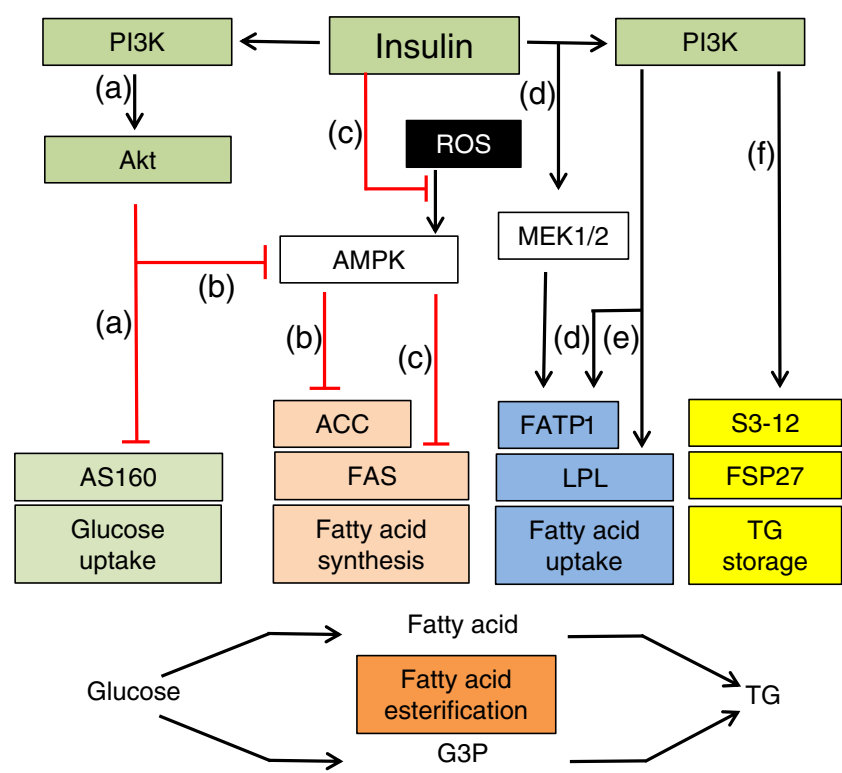

Fig. 2 Insulin signalling exerts rapid stimulation of glucose transport as well as fatty acid uptake, synthesis and esterification to triacylglycerol (TG). (a) Stimulation of the PI3K/Akt pathway by insulin leads to inhibition of AS160 and GLUT4 translocation. Glucose is converted to glycerol 3-phosphaate and fatty acids. (b) Insulinstimulated Akt may inhibit AMPK by phosphorylation. This in turn would lead to dephosphorylation and activation of ACC, increasing malonyl CoA production and de novo lipogenesis. (c) Reactive oxygen species (ROS) are reported to activate AMPK, which then phosphorylates and inhibits FAS. Insulin treatment decreases the inhibition of FAS induced by ROS. (d) Insulin increases fatty acid uptake by stimulating the translocation of FATP1 from intracellular vesicles to the plasma membrane mediated by PI3K or the MAPK pathway. (e) Insulin increases fatty acid uptake by stimulating LPL levels and activity through PI3K. (f) Insulin triacylglycerol synthesis or retention in adipocytes can be altered through regulation of lipid droplet protein S3-12 redistribution or FSP27 levels

acids enter the adipocyte by diffusion and by capture mediated by fatty acid transporter (FAT/CD36) and fatty acid transporter protein 1 (FATP1), which catalyses the conversion of fatty acids into fatty acyl-CoA [70]. Wu et al showed that insulinstimulated fatty acid uptake is completely abolished in FATP1null adipocytes and greatly reduced in the skeletal muscle of FATP1-knockout animals, while basal fatty acid uptake by both tissues was unaffected [72]. Insulin appears to increase fatty acid uptake in adipocytes by stimulating the translocation of FATP1 from intracellular vesicles to the plasma membrane [73]. Blocking PI3K or the MAPK pathway inhibits insulinstimulated translocation of FATP1 to the cell surface [73].

As mentioned above, insulin also increases the pool of adipocyte fatty acids for esterification through its acute stimulation of de novo lipogenesis, which mostly occurs in the liver and to a smaller extent in adipocytes. The inactivation by phosphorylation of a key enzyme in fatty acid synthesis, acetyl-CoA carboxylase (ACC), by AMPactivated protein kinase (AMPK) has been well established in isolated adipocytes [74-76]. Berggreen et al reported that, 
in adipocytes, insulin-stimulated Akt might regulate ACC by direct phosphorylation of AMPK, resulting in AMPK inhibition [77]. This in turn would lead to the dephosphorylation and activation of ACC, increasing malonyl CoA production and de novo lipogenesis (Fig. 2). Interestingly, fatty acid synthase (FAS), the last enzyme in the synthesis of fatty acids [78, 79], may also be regulated by AMPK under certain conditions [80].

Insulin might acutely stimulate triacylglycerol synthesis or retention in adipocytes through regulation of S3-12, an adipocyte-specific lipid droplet protein [81]. The formation of S3-12-coated lipid droplets in adipocytes apparently requires active triacylglycerol synthesis, which is insulindependent though PI3K activation. Treatment of 3T3-L1 adipocytes for $30 \mathrm{~min}$ with insulin was sufficient to redistribute S3-12 protein to lipid droplets [78], whereas a period of about $4 \mathrm{~h}$ was required for the upregulation of the lipid droplet protein FSP27 level by insulin [49]. Insulin may also facilitate the reformation of macro lipid droplets during recovery from lipolysis stimulation [82].

\section{Insulin-stimulated transcription of genes encoding lipogenic enzymes}

Although long-term insulin stimulation of lipogenesis involves major increases in the expression of genes encoding hepatic lipogenic enzymes [83-86], as depicted in Fig. 3 within the orange background, remarkably little is known about these mechanisms in adipocytes. Sterol regulatory element binding protein (SREBP) was originally identified as a transcription factor that binds to sterol regulatory elements in the promoter of the genes required for cholesterol regulation and adipocyte differentiation [87, 88]. Nuclear entry of SREBP requires proteolytic cleavage of the cytoplasmic N-terminal domain $[89,90]$, which is stimulated by insulin in hepatocytes $[88,89]$. Of the three members of the SREBP family-SREBP-1a, SREBP-1c and SREBP-2SREBP-1c is abundant in lipogenic tissues, and its transcription is induced by insulin [91]. SREBP-1c can stimulate the transcription of Glut4 [92] and many lipogenic genes, including, Fas, Lpl, Acc, Elovl6, Acl, Gpat, Dgat, Scd-1, and Scd-2 [87, 93], and strongly promotes de novo lipogenesis in liver. However, adipose-specific knockout of this factor had little or no phenotype in mice [94, 95]. Deficiency of SREBP-1c in mouse tissues can be accompanied by an elevation of SREBP-2 levels, which may be partially functionally redundant, so interpretation of these results is unclear and more work is needed to resolve this issue.

Insulin signalling to increase both SREBP-1c levels and processing is robust in liver (orange background in Fig. 3). Mechanisms may include a role of atypical PKC since a constitutively active $\mathrm{PKC} \lambda / \zeta$ in liver upregulated SREBP1c while an active Akt construct did not [96]. These data complement previously published studies on mouse knockouts indicating that atypical PKC activity is necessary for insulin stimulation of SREBP-1c levels [97]. In contrast, hepatic SREBP1c processing appears to be controlled by insulin through the Akt-mTOR pathway [98-100]. It was reported that $\mathrm{mTORC} 1$ mediates insulin-stimulated processing of SREBP-1c through its substrate protein kinase S6K, while the insulin signalling to stimulate SREBP-1c levels is less clear [101, 102]. Lipin-1, a phosphatidic acid phosphatase and a transcriptional co-activator, is a direct substrate of mTORC1 and a negative regulator of nuclear SREBP activity [98]. In mouse liver, nuclear transport of SREBP may be regulated by Akt signalling through control of INSIG-2 levels [100, 103]. The MAPK pathways, c-Jun N-terminal kinase, extracellular-signal-regulated kinase and p38 MAPK have been shown to phosphorylate SREBP-1a in liver [104, 105], and mutation of the SREBP-1a sites phosphorylated by the MAPKs in vivo abolished the transcriptional activation by SREBP1-a and protected mice from fatty liver and visceral obesity (not shown in Fig. 3) [105]. Thus, insulin acts at multiple regulatory steps to control the activity and levels of SREBPs in hepatocytes but, remarkably, none of these pathways has yet been carefully evaluated in adipocytes.

Two pathways that have been demonstrated to regulate expression of lipogenic genes downstream of insulin signalling in adipocytes are also depicted in Fig. 3 within the yellow background section. First, insulin regulates the binding of heterodimers of basic helix-loop-helix leucine zipper transcription factors upstream stimulatory factor-1 and -2 (USF1/USF2) to the Fas promoter in cultured adipocytes [86]. Consistent with these findings, USF null mice exhibit significantly impaired lipogenic gene induction in liver [106]. USF and SREBP-1c also interact in vitro and in vivo, while co-transfection of USF and SREBP-1c result in highly synergistic activation of the Fas promoter [84]. Insulin signalling through protein phosphatase- 1 has been proposed to dephosphorylate and activate the protein kinase DNAdependent protein kinase (DNA-PK), which in turn phosphorylates USF1 and increases transcriptional activation of FAS and de novo lipogenesis [107]. In DNA-PK-deficient severe combined immunodeficiency (SCID) mice, feedinginduced USF1 and FAS activation are impaired, resulting in decreased circulating triacylglycerol levels and reduced adiposity [108].

A second insulin-regulated lipogenic transcription factor in adipocytes is the carbohydrate response element-binding protein (ChREBP), also known to enhance lipogenesis in liver. Insulin-stimulated glucose uptake in adipocytes activates ChREBP, which upregulates de novo lipogenesis in adipose tissue [21]. The target genes of ChREBP are involved in glycolysis, lipogenesis and gluconeogenesis 


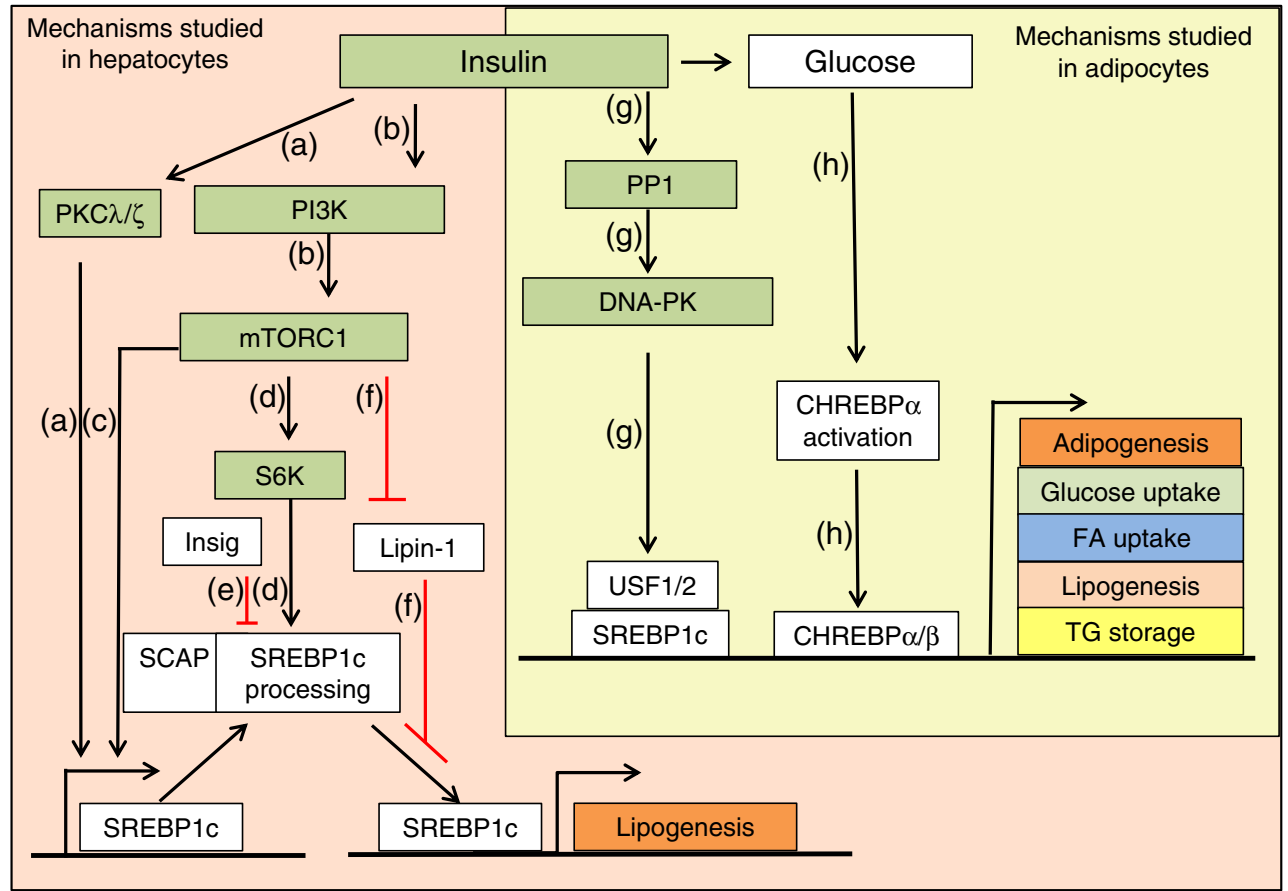

Fig. 3 Transcriptional regulation of lipogenic enzymes by insulin and glucose studied in hepatocytes (orange background) and adipocytes (yellow background). The degree to which the mechanisms discovered in liver apply to adipocytes is likely to be high, but this has not yet been established. (a) Insulin may increase the levels of active SREBP-1c through the atypical PKC PKC $\lambda / \zeta$ and (b) PI3K. (c) Activation of PI3K by insulin leads to increased SREBP-1c levels through mTORC1. (d) Insulin stimulates processing of SREBP-1c through the mTORC1 substrate S6K. (e) Insulin negatively regulates levels of Insig-2a, which inhibits SREBP processing. (f) Lipin-1 is a direct substrate of mTORC1 and a negative regulator of nuclear SREBP

[109-112]. During fasting, PKA and AMPK phosphorylate and inhibit ChREBP function [113]. Intermediates of glucose metabolism (xylulose 5-phosphate or glucose 6phosphate) may be essential for both ChREBP nuclear translocation and transcriptional activity in response to glucose in liver cells $[113,114]$. ChREBP ${ }^{-/-}$(also known as Mlxipl) mice display significantly reduced adipose tissue and are insulin resistant [108]; this is potentially due to dysfunctional adipocyte lipogenesis. Interestingly, glucoseinduced ChREBP $\alpha$ transcriptional activity increases the levels of a novel isoform, ChREBP $\beta$ (Fig. 3), which plays an even more active role in the regulation of lipogenic genes in adipose tissue [21]. While transgenic mice producing high levels of GLUT4 in adipose tissue improves insulin sensitivity, elevating adipocyte GLUT4 levels in ChREBP $P^{-/-}$ mice does not [21]. These data are consistent with the hypothesis that adipocyte lipogenesis stimulated by insulin is important in regulating whole body metabolism, perhaps by generating beneficial lipids that can affect whole body insulin sensitivity [115]. That insulin signalling is important for adipocyte lipogenesis is reinforced by data showing that adipose- activity. Once active, SREBP can induce the transcription of lipogenic genes. (g) Insulin-stimulated protein phosphatase-1 (PP1) dephosphorylates and activates DNA-PK, which in turn phosphorylates USF1/2. By interacting with SREBP, USF1/2 increases expression of Fas and de novo lipogenesis. (h) Insulin-stimulated glucose uptake in adipocytes activates $\operatorname{ChREBP} \alpha$, which stimulates production of its isoform ChREBP $\beta$. The target genes of SREBP $1 c$ and ChREBP $\alpha$ and ChREBP $\beta$ are involved in adipogenesis, glucose uptake, glycolysis, lipogenesis, and triacylglycerol (TG) storage. FA, fatty acid; SCAP, SREBP cleavage-activating protein

specific knockout of the insulin receptor leads to lower adipose mass $[116,117]$.

\section{Adipose tissue immune cells and their bioactive factors that effect lipogenesis}

Expansion of fat mass in obesity is accompanied by infiltration of cells of innate and adaptive immunity, including macrophages, T cells, B cells, natural killer T cells, neutrophils, eosinophils and mast cells [118-123]. Macrophages are the most abundant immune cell population in adipose tissue in obesity [120], and are the main source of proinflammatory molecules (e.g. TNF- $\alpha$, IL1 $\beta$ ) secreted in adipose tissue in the obese state [124, 125]. Macrophages may be attracted into adipose tissue by increased fatty acid release from either viable or dying adipocytes in obesity [126, 127], which may shift their phenotype from M2 towards the M1 pro-inflammatory phenotype [128]. Adipose tissue macrophages can also accumulate lipids and become 'foam cell like-cells' [129], which may complement 
adipocyte lipid sequestration in adipose tissue. While much of the relevant literature suggests macrophages in adipose tissue inhibit adipose function $[125,130]$, some data indicate a beneficial role, for example, in attenuating lipolysis [128].

$\mathrm{T}$ lymphocytes represent the second most abundant immune cell population in adipose tissue and might accelerate adipose tissue macrophage recruitment and activation [131, 132]. Levels of pro-inflammatory $\mathrm{CD} 8^{+}$and $\mathrm{IFN} \gamma^{+} \mathrm{T}$ helper (Th) type 1 cells appear to increase with obesity, while levels of anti-inflammatory IL $4^{+} \mathrm{Th} 2$ and regulatory T cells appear to decrease in adipose tissue from obese mice and humans [133-137]. Thus, T cells may mediate inhibitory effects on insulin action and lipogenic genes [135, 136]. Th17 cells producing IL17 may impair adipose tissue metabolism via inhibition of adipogenesis and decreased glucose uptake [137, 138]. IL17-deficient mice gained weight but sustained glucose tolerance under high-fat diet (HFD) conditions [139]. In addition, natural killer T lymphocytes in adipose tissue are activated by binding to lipids or glycolipids associated with the protein CD1d. Although these and other immune cells represent a very low percentage of the adipose tissue total, a role in obesity-induced insulin resistance is suggested by their experimental depletion in mice $[119,121,122,140]$. Macrophages and lymphocytes can also become insulin resistant [141]. Indeed, depletion of insulin receptor in myeloid cells protected mice from HFDinduced insulin resistance and adipose tissue inflammation $[142,143]$.

Table 1 summarises the major factors produced by infiltrating immune cells in adipose tissue of obese rodents and humans and their reported effects on adipose tissue metabolism and insulin signalling. These include a broad range of pro-inflammatory cytokines, including TNF- $\alpha$, IL1 $\beta$, IL6, and IFN $\gamma$, whose negative effect on insulin signalling is indicated in several studies using knockout animals and other approaches $[125,144,145]$. Furthermore, TNF- $\alpha$ injection or adipocyte-specific production of the active transmembrane form of TNF- $\alpha$ exacerbates systemic and local insulin resistance, respectively [146-148]. IFN $\gamma$, produced by $\mathrm{Th} 1$ and $\mathrm{CD} 8^{+}$lymphocytes, also downregulates insulin signalling and adipogenesis, while increasing lipolysis [149]. Moreover, depletion of IFN $\gamma$ protects mice from HFD-induced insulin resistance [150]. IL17 secreted by Th17 cells in adipose tissue also negatively regulates adipocyte lipid metabolism [139]. The production of inflammatory lipid mediators such as 12/15-lipoxygenase products (leukotrienes, hydroxyeicosatetraenoic acids) may add to the detrimental effect on lipid metabolism in adipocytes by inducing the secretion of pro-inflammatory cytokines [151, 152]. Studies in humans and rodents continue to reveal novel inflammatory molecules from the chemokine or interleukin families that influence adipose tissue insulin signalling and lipid storage, exemplified by CCL7, CXCL5, IL7 and IL33 [153-155].

Anti-inflammatory cytokines IL4, IL10 and IL1 receptor antagonist (IL1Ra), which blunt the actions of proinflammatory cytokines on insulin signalling can also be measured in adipose tissue of obese individuals [128, $156-158]$. For example, IL10 inhibits TNF- $\alpha$ production in macrophages [158], while transgenic mice producing elevated levels of IL10 show improved insulin sensitivity under HFD conditions [159]. Recent studies suggest that IL4 enhances insulin action in adipose tissue, promoting activation of Akt and inhibition of glycogen synthase kinase- $3 \beta$, attenuating adipose tissue inflammation $[156,160]$. A key point from these studies is that immune cells can secrete both beneficial and deleterious factors within adipose depots, and the overall effect under a given physiological condition represents the integration of the effects of these multiple factors in real time.

\section{Mechanisms of insulin resistance of adipocyte lipogenesis}

Prior to discoveries starting in the 1980s that uncovered the molecules of insulin signalling, the problem of insulin resistance was viewed as simply whether obesity mostly impaired insulin binding to its receptor vs 'post-receptor' signalling events. Insulin binding to adipocytes was indeed found to be inhibited in obesity, reflecting a decrease in the number of adipocyte surface receptors [161, 162] following induction of receptor endocytosis in response to insulin binding [163, 164]. However, the remaining receptors were calculated to be sufficient to mediate a full response at high insulin concentrations, which is at odds with the greatly decreased maximum response of lipogenesis that was observed $[165,166]$.

We now know that tyrosine phosphorylation of IRS proteins and activation of Akt2, the major insulin signalling pathway leading to glucose transport stimulation $[53,58]$, are also blunted in adipocytes from obese mice $[167,168]$ and obese, insulin-resistant humans [169-171]. Mechanisms for this impaired signalling could include inhibition of IRS function by the negative feedback loop from S6K [172] and inhibition of mTORC2-mediated Akt2 phosphorylation and activation, also through negative regulation by S6K [173] (Fig. 1). This concept is consistent with the hypothesis that the hyperinsulinaemia associated with obesity may actually be the cause, rather than simply the consequence, of insulin resistance via such feedback inhibition [165]. Other major candidates for obesity-mediated attenuation of insulin signalling to Akt2 in adipocytes in obesity include (1) factors secreted from immune cells in adipose tissue, as described in the section above; (2) factors secreted from endothelial cells [174, 175]; (3) factors from neuronal innervation of adipose 
Table 1 Effects of cytokines on insulin signalling, glucose uptake, lipogenesis and lipolysis in adipocytes and on hepatic lipogenesis

\begin{tabular}{|c|c|c|c|c|c|c|c|}
\hline Molecule & $\begin{array}{l}\text { Effect on in } \\
\text { vitro adipocyte } \\
\text { insulin signalling }\end{array}$ & $\begin{array}{l}\text { Effect on in } \\
\text { vitro adipocyte } \\
\text { glucose uptake }\end{array}$ & $\begin{array}{l}\text { Effect on in } \\
\text { vitro adipocyte } \\
\text { lipogenesis }\end{array}$ & $\begin{array}{l}\text { Effect on in } \\
\text { vitro adipocyte } \\
\text { lipolysis }\end{array}$ & $\begin{array}{l}\text { Insulin } \\
\text { sensitivity } \\
\text { KO mice }\end{array}$ & $\begin{array}{l}\text { Triacylglycerol } \\
\text { synthesis } \\
\text { KO mice }\end{array}$ & Ref. \\
\hline TNF- $\alpha$ & $\downarrow$ IRS1, Akt & $\downarrow$ GLUT4 & $\begin{array}{l}\downarrow \text { PPAR } \gamma, \text { SREBP1c, } \\
\text { ACS, SCD1, } \\
\text { LPL, aP2 }\end{array}$ & $\uparrow A T G L$, HSL & $\uparrow$ & $\downarrow$ (Liver) & $\begin{array}{l}{[125,144,148,202,} \\
\quad 232-235]\end{array}$ \\
\hline $\operatorname{IL} 1 \beta$ & $\downarrow$ IRS1, Akt & $\downarrow$ GLUT4 & $\begin{array}{l}\downarrow \text { PPAR } \gamma, \text { SREBP } 1 \mathrm{c}, \\
\text { ACC, FAS }\end{array}$ & $\uparrow H S L$ & $\uparrow$ & $\downarrow$ (Liver) & [236-238] \\
\hline IL6 & $\downarrow$ IRS1, Akt & $\downarrow$ GLUT4 & $\downarrow$ PPAR $\gamma$, FAS, aP2 & $\uparrow$ & $\downarrow$ & $\uparrow$ (Liver) & {$[145,239-241]$} \\
\hline $\mathrm{IFN} \gamma$ & $\downarrow$ IRS1, IR, Akt & $\downarrow$ GLUT4 & $\downarrow$ LPL, FAS, PPAR $\gamma$ & $\uparrow$ & $\uparrow$ & & {$[134,149,150,242$} \\
\hline IL17 & & $\downarrow$ GLUT4 & $\downarrow$ PPAR $\gamma$, PLIN & & $\uparrow$ & & [139] \\
\hline $\begin{array}{l}\text { Lipoxygenase } \\
\text { products }\end{array}$ & $\downarrow$ IRS1, Akt & & & $\uparrow H S L$ & $\uparrow$ & & {$[150,151]$} \\
\hline IL4 & $\uparrow A k t \downarrow$ GSK-3 $\beta$ & & $\downarrow$ & & $\downarrow$ & $\uparrow$ (Liver) & {$[156,160]$} \\
\hline IL10 & $\uparrow A k t$ & $\uparrow$ & & & $\leftrightarrow$ & & {$[128,158,159,243$} \\
\hline IL1Ra & & & $\uparrow \mathrm{LPL}$ activity, PPAR $\gamma$ & & $\uparrow$ & & {$[244-246]$} \\
\hline
\end{tabular}

First four columns: major bioactive molecules produced by immune cells that can modulate adipocyte insulin signalling elements, GLUT4 and glucose uptake, conversion of precursors to triacylglycerol (lipogenesis), and glycerol and fatty acid release (lipolysis) in vitro ( $\downarrow$ inhibitory effect, $\uparrow$ stimulatory effect)

Last two columns: effects of gene knockout of indicated cytokines on whole body insulin sensitivity or triacylglycerol synthesis in indicated tissue ACS, acyl-CoA synthetase; aP2, adipocyte protein 2; GSK-3 $\beta$, glycogen synthase kinase-3 $\beta$; IR, insulin receptor; LPL, lipoprotein lipase; PLIN, perilipin; SCD, stearoyl-CoA desaturase

tissue [176-178]; and (4) increased influx of fatty acids into adipocytes, particularly palmitate $[179,180]$. It should be noted that insulin itself may modulate the production of cytokines [142, 181-186]. Moreover, hyperinsulinaemic clamp conditions in humans cause increased cytokine secretion by adipose tissue [187, 188]. Thus, hyperinsulinaemia may act synergistically with adipose tissue immune cells in producing insulin resistance.

The potential mechanisms for inhibition of insulin signalling to Akt by the above factors have been extensively reviewed [189, 190]. Much experimental emphasis has been placed on Ser/Thr phosphorylation of IRS proteins by various protein kinases activated by the factors listed above, leading to inhibition of IRS tyrosine phosphorylation and its signalling through PI3K [191]. However, an underappreciated aspect of insulin resistance in adipose tissue is the fact that inhibition of insulin receptor signalling to Akt is not sufficient to explain the degree to which insulin-stimulated lipogenesis is suppressed in adipocytes under physiological glucose concentrations [192-195]. Stimulated Akt activity is in large excess over that needed to fully upregulate glucose transport in adipocytes, and even large inhibitions of its activity, as occurs in obesity, are unlikely to fully account for the great diminutions of acute glucose conversion to triacylglycerol observed [195]. Thus, a key concept is that attenuation of the upstream insulin signalling pathway to Akt in obesity is only one contributor, and possibly a minor one, to what is measured as resistance of lipogenesis to insulin in adipocytes.
It is well established that, in human obesity, adipocyte enzymes involved in fatty acid esterification and de novo fatty acid synthesis pathways are markedly reduced [196]. These include diacylglycerol acyltransferase in the former pathway and ATP citrate lyase, ACC and FAS in the latter [197]. The decreased level of lipogenic enzymes is also observed in most rodent models of obesity [198, 199]. Furthermore, it has been shown that large adipocytes from old obese rats exhibit higher rates of glucose transport per cell than small adipocytes from lean animals, even though insulin-stimulated conversion of radiolabelled glucose to triacylglycerol, glycerol and fatty acids is completely blocked in the former [192]. Taken together, these data indicate that the uptake of glucose into the adipocyte may not be the major rate-limiting step in obesity but, rather, the enzymatic capacity to convert it to triacylglycerol is limited. Thus, in this sense, the term 'insulin resistance' may be a misnomer in that the major physiological impairment is in the end target of insulin action (lipogenic enzyme deficit) rather than solely in the initial insulin signalling pathway.

It is confounding that hepatic lipogenesis is greatly enhanced in response to hyperinsulinaemia in obesity, while adipocyte lipogenic capacity is attenuated under these same conditions. One explanation for the increased hepatic lipogenesis in obesity appears to be activation of mTORC 1 by the excess nutrient amino acids, causing stimulation of one of its known downstream targets, the lipogenic transcription factor SREBP1 [98-100]. In contrast, SREBP1 abundance and processing to its active, truncated form in adipocytes is 
decreased in obesity [198-202], even though mTOR and S6K activities are apparently actually increased in the adipose tissue of obese mice [172]. One possible answer to this paradox relates to the selective negative influence on lipogenesis of certain immune cell factors and cytokines elevated in adipose tissue in obesity (Fig. 4). In obesity, immune cell infiltration in adipose tissue is more severe than that observed in liver [203, 204]. Strikingly, TNF- $\alpha$ greatly decreases adipose tissue levels of peroxisome proliferatoractivated receptor $\gamma(\operatorname{PPAR} \gamma)$ and its target SREBP1 [191, 202, 205], while it increases SREBP1 levels and processing in liver through mechanisms independent of PPAR $\gamma$ [206, 207]. The negative regulation of PPAR $\gamma$ in adipocytes by TNF- $\alpha$ appears to include decreases in PPAR $\gamma$ transcription, PPAR $\gamma$ mRNA stability and protein turnover $[191,208$, 209]. Phosphorylation of PPAR $\gamma$ by protein kinases upregulated in obesity may be part of this inhibitory pattern [210]. PPAR $\gamma$, in turn, stimulates transcription and activation of SREBP1c, as well as acting directly on the promoters of many genes encoding lipogenic enzymes and factors [211-213]. The latter include lipid droplet proteins that help

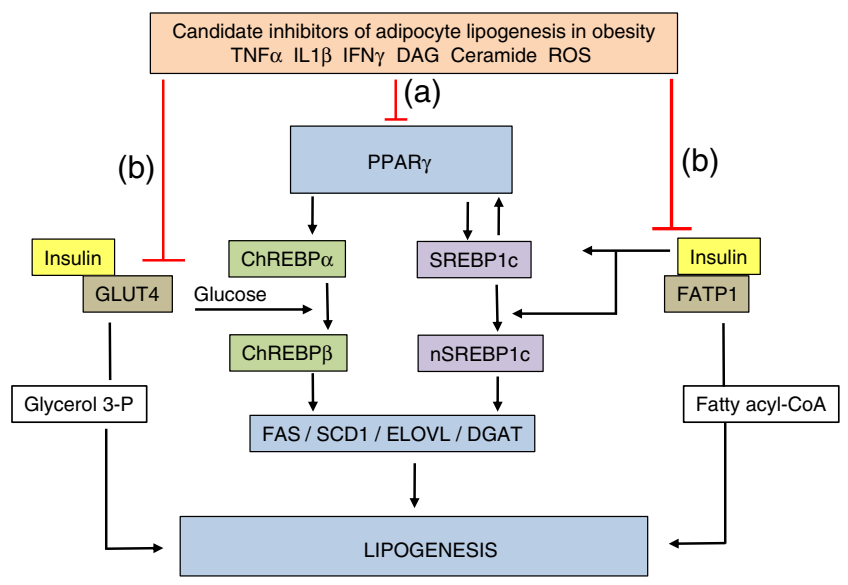

Fig. 4 PPAR $\gamma$ as a key regulator of lipogenesis in adipocytes and hypothetical major target for inhibitors of insulin-stimulated lipogenesis in obesity. Adipocytes from obese rodents and humans display decreased levels of lipogenic transcription factors (SREBP1c and ChREBP) and lipogenic enzymes (FAS, SCD1, ELOVL, DGAT) compared with lean controls. (a) Attenuation of PPAR $\gamma$ by candidate inhibitors generated in obesity would explain the downregulation of all of these proteins. Direct inhibition of the lipogenic transcription factors and enzymes by such inhibitors is also possible. (b) Inhibition of early steps in insulin signalling is also evident in adipocytes in obesity, through attenuation of IRS tyrosine phosphorylation and other inhibitory mechanisms, as shown in Fig. 1. While the factors listed as candidate inhibitors in the top box can be shown in vitro to exert such effects, the extent to which they contribute to insulin resistance in adipocytes in vivo remains to be fully elucidated. It should be noted that PPAR $\gamma$ also stimulates production of the enzyme phosphoenolpyruvate carboxykinase (not shown in the Figure), which in turn stimulates lipogenesis through the pathway of glyceroneogenesis [55]. Thus PPAR $\gamma$ disruption will also lead to attenuation of this pathway. DGAT, diglyceride acyltransferase; ELOVL, elongation of long-chain fatty acids; ROS, reactive oxygen species; SCD1, stearoyl-CoA desaturase to sequester triacylglycerol in the droplets, protected from lipolytic enzymes [214-216]. Other cytokines such as IL1, which are released by macrophages in adipose tissue of obese individuals [124, 217], mediate similar attenuations of PPAR $\gamma$ activity or levels [210]. Additionally, since insulin signalling through Akt and mTORC1 causes processing and activation of SREBP1c [98-100] (Fig. 3), the attenuated activation of Akt in obesity may contribute to decreased SREBP1c activity.

It is remarkable that key experiments have not yet been performed to verify even the most popular hypotheses related to adipose dysfunction in obesity. For example, testing the concept that adipose inflammation by immune cells is a cause of systemic glucose intolerance would require immune cells to be experimentally depleted in adipose tissue while being maintained in other tissues. This critical experiment is a technically difficult one, and has not been accomplished to date. Furthermore, several anti-inflammatory strategies have been tested in metabolic disease with little success [218-220], indicating more research is necessary to unravel the role of adipose tissue inflammation in diabetes.

Another major regulatory pathway of triacylglycerol synthesis involves the ability of glucose to increase the activity of $\operatorname{ChREBP} \alpha$, which promotes the expression of lipogenic genes [21]. Similar to SREBP1c, hepatic ChREBP $\alpha$ levels are increased in obesity, while adipocyte ChREBP $\alpha$ is decreased [221-223]. In adipose tissue, unlike liver, insulin stimulates glucose uptake thus enhancing ChREBP $\alpha$ function. Levels of the GLUT4 protein itself are substantially decreased in adipocytes of obese mice and humans [224, 225]. Recent work revealed that ChREBP $\beta$ levels are increased by ChREBP $\alpha$, and is even more potent in stimulating transcription of lipogenic genes [21]. Adipose-specific depletion of GLUT4 decreases abundance of ChREBP $\alpha$ and ChREBP $\beta$, while increased GLUT4 elevates their levels [21], indicating that the deficit in GLUT4 in obesity may contribute to the observed downregulation of these lipogenic factors. Furthermore, ChREBP $\alpha$ is also a downstream target of PPAR $\gamma$ [222], which is often decreased in adipocytes in obesity as discussed above. Taken together, these results indicate that dysfunctions in the ChREBP pathway contribute to adipose lipogenic deficiency in obesity.

Since the transcription factors SREBP1c and ChREBP, along with the many genes that encode lipogenic enzymes themselves, are all downstream of PPAR $\gamma$, direct obstruction of this master regulator in obesity is expected to decrease adipocyte lipogenesis capacity (Fig. 4). Such effects of PPAR $\gamma$ inhibition are further magnified by the simultaneous disruption of downstream feed-forward cycles. For example, the downstream target enzyme FAS catalyses synthesis of palmitate, which can apparently be converted to derivatives that act as PPAR $\gamma$ ligands [226-228]. Thus, decrements in FAS due to PPAR $\gamma$ attenuation, reduces the extent to which 
the remaining PPAR $\gamma$ can be activated. Furthermore, PPAR $\gamma$ upregulates elements of the insulin signalling pathway such as IRS-1 [229-231], suggesting that suppression of the upstream insulin signalling pathway to Akt in obesity is also in part secondary to PPAR $\gamma$ inhibition in obesity.

\section{Perspectives}

The role of adipose tissue as the primary depot for robust triacylglycerol storage in humans appears to be an important factor in preventing systemic insulin resistance and diabetes in response to obesity. Insulin signalling maintains this high capacity for triacylglycerol synthesis and storage in adipose tissue in healthy humans, but chronic hyperinsulinaemia, increased cytokines and other abnormal secretions from cells within adipose tissue are among the dysfunctions in obesity that may contribute to a decrease in this capacity. Thus, to fully understand the relationships between adipose tissue function and whole body glucose tolerance, it is crucial to unravel the underlying mechanisms of insulin signalling, insulin resistance and control of lipogenesis in adipose. Two basic key questions among many others remain unanswered to date: What are the signals that downregulate adipose lipogenic transcription factors and lipogenic enzymes in obesity? Do the cytokines released in adipose tissue by immune cells in obesity contribute to the downregulation of adipocyte lipogenesis in vivo? Finding truly innovative approaches to answer these questions will surely move this field forward and potentially yield new therapeutic strategies for treating type 2 diabetes.

Acknowledgements We thank Drs. Adilson Guilherme, Joseph Virbasius and members of our laboratory at University of Massachusetts, Worcester, MA, USA for excellent discussion of the issues discussed in this review.

Funding Studies from our laboratory related to this topic are supported by grants to M. P. Czech from the National Institutes of Health (DK085753, DK030898) and from the International Research Alliance at the Novo Nordisk Foundation Center for Metabolic Research.

Duality of interest The authors declare that there is no duality of interest associated with this manuscript.

Contribution statement All authors were responsible for the conception and design of the manuscript, drafting the article and revising it critically for important intellectual content. All authors approved the version to be published.

\section{References}

1. Tattersall RB (1995) A force of magical activity: the introduction of insulin treatment in Britain 1922-1926. Diabet Med 12:739-755
2. Dentin R, Girard J, Postic C (2005) Carbohydrate responsive element binding protein (ChREBP) and sterol regulatory element binding protein-1c (SREBP-1c): two key regulators of glucose metabolism and lipid synthesis in liver. Biochimie 87:81-86

3. Frayn KN (1998) Regulation of fatty acid delivery in vivo. Adv Exp Med Biol 441:171-179

4. Frayn KN (2001) Adipose tissue and the insulin resistance syndrome. Proc Nutr Soc 60:375-380

5. Boden G (2001) Free fatty acids - the link between obesity and insulin resistance. Endocr Pract 7:44-51

6. Samuel VT, Petersen KF, Shulman GI (2010) Lipid-induced insulin resistance: unravelling the mechanism. Lancet 375:22672277

7. McGarry JD (1992) What if Minkowski had been ageusic? An alternative angle on diabetes. Science 258:766-770

8. Chavez JA, Summers SA (2010) Lipid oversupply, selective insulin resistance, and lipotoxicity: molecular mechanisms. Biochim Biophys Acta 1801:252-265

9. Samuel VT, Shulman GI (2012) Mechanisms for insulin resistance: common threads and missing links. Cell 148:852-871

10. Dresner A, Laurent D, Marcucci M et al (1999) Effects of free fatty acids on glucose transport and IRS-1-associated phosphatidylinositol 3-kinase activity. J Clin Invest 103:253-259

11. Holland WL, Bikman BT, Wang LP et al (2011) Lipid-induced insulin resistance mediated by the proinflammatory receptor TLR4 requires saturated fatty acid-induced ceramide biosynthesis in mice. J Clin Invest 121:1858-1870

12. Hoy AJ, Brandon AE, Turner $N$ et al (2009) Lipid and insulin infusion-induced skeletal muscle insulin resistance is likely due to metabolic feedback and not changes in IRS-1, Akt, or AS160 phosphorylation. Am J Physiol Endocrinol Metab 297:E67-E75

13. Roden M, Price TB, Perseghin G et al (1996) Mechanism of free fatty acid-induced insulin resistance in humans. J Clin Invest 97:2859-2865

14. Schmitz-Peiffer C, Craig DL, Biden TJ (1999) Ceramide generation is sufficient to account for the inhibition of the insulinstimulated PKB pathway in $\mathrm{C} 2 \mathrm{C} 12$ skeletal muscle cells pretreated with palmitate. J Biol Chem 274:24202-24210

15. Sinha S, Perdomo G, Brown NF, O’Doherty RM (2004) Fatty acid-induced insulin resistance in L6 myotubes is prevented by inhibition of activation and nuclear localization of nuclear factor kappa B. J Biol Chem 279:41294-41301

16. Stratford S, Hoehn KL, Liu F, Summers SA (2004) Regulation of insulin action by ceramide: dual mechanisms linking ceramide accumulation to the inhibition of Akt/protein kinase B. J Biol Chem 279:36608-36615

17. Karpe F, Dickmann JR, Frayn KN (2011) Fatty acids, obesity, and insulin resistance: time for a reevaluation. Diabetes 60:24412449

18. Li P, Fan W, Xu J et al (2011) Adipocyte NCoR knockout decreases PPARgamma phosphorylation and enhances PPARgamma activity and insulin sensitivity. Cell 147:815-826

19. Sugii S, Olson P, Sears DD et al (2009) PPARgamma activation in adipocytes is sufficient for systemic insulin sensitization. Proc Natl Acad Sci U S A 106:22504-22509

20. Chen HC, Stone SJ, Zhou P, Buhman KK, Farese RV Jr (2002) Dissociation of obesity and impaired glucose disposal in mice overexpressing acyl coenzyme A:diacylglycerol acyltransferase 1 in white adipose tissue. Diabetes 51:3189-3195

21. Herman MA, Peroni OD, Villoria J et al (2012) A novel ChREBP isoform in adipose tissue regulates systemic glucose metabolism. Nature 484:333-338

22. Kusminski CM, Holland WL, Sun K et al (2012) MitoNEETdriven alterations in adipocyte mitochondrial activity reveal a crucial adaptive process that preserves insulin sensitivity in obesity. Nat Med 18:1539-1549 
23. Shepherd PR, Gnudi L, Tozzo E, Yang H, Leach F, Kahn BB (1993) Adipose cell hyperplasia and enhanced glucose disposal in transgenic mice overexpressing GLUT4 selectively in adipose tissue. J Biol Chem 268:22243-22246

24. Brasaemle DL (2007) Thematic review series: adipocyte biology. The perilipin family of structural lipid droplet proteins: stabilization of lipid droplets and control of lipolysis. J Lipid Res 48:2547-2559

25. Duncan RE, Ahmadian M, Jaworski K, Sarkadi-Nagy E, Sul HS (2007) Regulation of lipolysis in adipocytes. Annu Rev Nutr 27:79-101

26. Martinez-Botas J, Anderson JB, Tessier D et al (2000) Absence of perilipin results in leanness and reverses obesity in $L e p r^{d b / d b}$ mice. Nat Genet 26:474-479

27. Puri V, Konda S, Ranjit S et al (2007) Fat-specific protein 27, a novel lipid droplet protein that enhances triglyceride storage. J Biol Chem 282:34213-34218

28. Haemmerle G, Zimmermann R, Strauss JG et al (2002) Hormonesensitive lipase deficiency in mice changes the plasma lipid profile by affecting the tissue-specific expression pattern of lipoprotein lipase in adipose tissue and muscle. J Biol Chem 277:12946-12952

29. Taschler U, Radner FP, Heier C et al (2011) Monoglyceride lipase deficiency in mice impairs lipolysis and attenuates diet-induced insulin resistance. J Biol Chem 286:1746717477

30. Zechner R, Zimmermann R, Eichmann TO et al (2012) Fat signals - lipases and lipolysis in lipid metabolism and signaling. Cell Metab 15:279-291

31. Zimmermann R, Strauss JG, Haemmerle G et al (2004) Fat mobilization in adipose tissue is promoted by adipose triglyceride lipase. Science 306:1383-1386

32. Gruber A, Cornaciu I, Lass A et al (2010) The N-terminal region of comparative gene identification-58 (CGI-58) is important for lipid droplet binding and activation of adipose triglyceride lipase. J Biol Chem 285:12289-12298

33. Lass A, Zimmermann R, Haemmerle G et al (2006) Adipose triglyceride lipase-mediated lipolysis of cellular fat stores is activated by CGI-58 and defective in Chanarin-Dorfman Syndrome. Cell Metab 3:309-319

34. Miyoshi H, Perfield JW 2nd, Souza SC et al (2007) Control of adipose triglyceride lipase action by serine 517 of perilipin A globally regulates protein kinase A-stimulated lipolysis in adipocytes. J Biol Chem 282:996-1002

35. Shen WJ, Patel S, Miyoshi H, Greenberg AS, Kraemer FB (2009) Functional interaction of hormone-sensitive lipase and perilipin in lipolysis. J Lipid Res 50:2306-2313

36. Bordicchia M, Liu D, Amri EZ et al (2012) Cardiac natriuretic peptides act via p38 MAPK to induce the brown fat thermogenic program in mouse and human adipocytes. J Clin Invest 122:1022-1036

37. Moro C, Galitzky J, Sengenes C, Crampes F, Lafontan M, Berlan $M$ (2004) Functional and pharmacological characterization of the natriuretic peptide-dependent lipolytic pathway in human fat cells. J Pharmacol Exp Ther 308:984-992

38. Sengenes C, Berlan M, de Glisezinski I, Lafontan M, Galitzky J (2000) Natriuretic peptides: a new lipolytic pathway in human adipocytes. FASEB J 14:1345-1351

39. Sengenes C, Bouloumie A, Hauner $H$ et al (2003) Involvement of a cGMP-dependent pathway in the natriuretic peptide-mediated hormone-sensitive lipase phosphorylation in human adipocytes. J Biol Chem 278:48617-48626

40. Wang TJ, Larson MG, Levy D et al (2004) Impact of obesity on plasma natriuretic peptide levels. Circulation 109:594-600

41. Cantley LC (2002) The phosphoinositide 3-kinase pathway. Science 296:1655-1657
42. Taniguchi CM, Emanuelli B, Kahn CR (2006) Critical nodes in signalling pathways: insights into insulin action. Nat Rev Mol Cell Biol 7:85-96

43. Duncan RE, Sarkadi-Nagy E, Jaworski K, Ahmadian M, Sul HS (2008) Identification and functional characterization of adiposespecific phospholipase A2 (AdPLA). J Biol Chem 283:2542825436

44. Jaworski K, Ahmadian M, Duncan RE et al (2009) AdPLA ablation increases lipolysis and prevents obesity induced by high-fat feeding or leptin deficiency. Nat Med 15:159-168

45. Eriksson H, Ridderstrale M, Degerman E et al (1995) Evidence for the key role of the adipocyte cGMP-inhibited cAMP phosphodiesterase in the antilipolytic action of insulin. Biochim Biophys Acta 1266:101-107

46. Kitamura T, Kitamura Y, Kuroda S et al (1999) Insulin-induced phosphorylation and activation of cyclic nucleotide phosphodiesterase $3 \mathrm{~B}$ by the serine-threonine kinase Akt. Mol Cell Biol 19:6286-6296

47. Rahn T, Ridderstrale M, Tornqvist $\mathrm{H}$ et al (1994) Essential role of phosphatidylinositol 3-kinase in insulin-induced activation and phosphorylation of the cGMP-inhibited cAMP phosphodiesterase in rat adipocytes. Studies using the selective inhibitor wortmannin. FEBS Lett 350:314-318

48. Chakrabarti P, English T, Shi J, Smas CM, Kandror KV (2010) Mammalian target of rapamycin complex 1 suppresses lipolysis, stimulates lipogenesis, and promotes fat storage. Diabetes 59:775-781

49. Kim JY, Liu K, Zhou S, Tillison K, Wu Y, Smas CM (2008) Assessment of fat-specific protein 27 in the adipocyte lineage suggests a dual role for FSP27 in adipocyte metabolism and cell death. Am J Physiol Endocrinol Metab 294:E654-E667

50. Cheatham B, Vlahos CJ, Cheatham L, Wang L, Blenis J, Kahn CR (1994) Phosphatidylinositol 3-kinase activation is required for insulin stimulation of pp 70 S6 kinase, DNA synthesis, and glucose transporter translocation. Mol Cell Biol 14:4902-4911

51. Cushman SW, Wardzala LJ (1980) Potential mechanism of insulin action on glucose transport in the isolated rat adipose cell. Apparent translocation of intracellular transport systems to the plasma membrane. J Biol Chem 255:4758-4762

52. Guilherme A, Czech MP (1998) Stimulation of IRS-1-associated phosphatidylinositol 3-kinase and Akt/protein kinase B but not glucose transport by beta1-integrin signaling in rat adipocytes. J Biol Chem 273:33119-33122

53. Huang S, Czech MP (2007) The GLUT4 glucose transporter. Cell Metab 5:237-252

54. Suzuki K, Kono T (1980) Evidence that insulin causes translocation of glucose transport activity to the plasma membrane from an intracellular storage site. Proc Natl Acad Sci U S A 77:25422545

55. Nye C, Kim J, Kalhan SC, Hanson RW (2008) Reassessing triglyceride synthesis in adipose tissue. Trends Endocrinol Metab 19:356-361

56. Farese RV, Sajan MP, Standaert ML (2005) Atypical protein kinase $\mathrm{C}$ in insulin action and insulin resistance. Biochem Soc Trans 33:350-353

57. Kotani K, Ogawa W, Matsumoto M et al (1998) Requirement of atypical protein kinase clambda for insulin stimulation of glucose uptake but not for Akt activation in 3T3-L1 adipocytes. Mol Cell Biol 18:6971-6982

58. Cho H, Mu J, Kim JK et al (2001) Insulin resistance and a diabetes mellitus-like syndrome in mice lacking the protein kinase Akt2 (PKB beta). Science 292:1728-1731

59. Jiang ZY, Zhou QL, Coleman KA, Chouinard M, Boese Q, Czech MP (2003) Insulin signaling through Akt/protein kinase B analyzed by small interfering RNA-mediated gene silencing. Proc Natl Acad Sci U S A 100:7569-7574 
60. Eguez L, Lee A, Chavez JA et al (2005) Full intracellular retention of GLUT4 requires AS160 Rab GTPase activating protein. Cell Metab 2:263-272

61. Kane S, Sano H, Liu SC et al (2002) A method to identify serine kinase substrates. Akt phosphorylates a novel adipocyte protein with a Rab GTPase-activating protein (GAP) domain. J Biol Chem 277:22115-22118

62. Zerial M, McBride H (2001) Rab proteins as membrane organizers. Nat Rev Mol Cell Biol 2:107-117

63. Chen S, Wasserman DH, MacKintosh C, Sakamoto K (2011) Mice with AS160/TBC1D4-Thr649Ala knockin mutation are glucose intolerant with reduced insulin sensitivity and altered GLUT4 trafficking. Cell Metab 13:68-79

64. Gonzalez E, McGraw TE (2006) Insulin signaling diverges into Akt-dependent and -independent signals to regulate the recruitment/docking and the fusion of GLUT4 vesicles to the plasma membrane. Mol Biol Cell 17:4484-4493

65. Picard F, Naimi N, Richard D, Deshaies Y (1999) Response of adipose tissue lipoprotein lipase to the cephalic phase of insulin secretion. Diabetes 48:452-459

66. Semenkovich CF, Wims M, Noe L, Etienne J, Chan L (1989) Insulin regulation of lipoprotein lipase activity in 3T3-L1 adipocytes is mediated at posttranscriptional and posttranslational levels. J Biol Chem 264:9030-9038

67. Gonzales AM, Orlando RA (2007) Role of adipocyte-derived lipoprotein lipase in adipocyte hypertrophy. Nutr Metab (Lond) 4:22

68. Sadur CN, Eckel RH (1982) Insulin stimulation of adipose tissue lipoprotein lipase. Use of the euglycemic clamp technique. J Clin Invest 69:1119-1125

69. Yki-Jarvinen H, Taskinen MR, Koivisto VA, Nikkila EA (1984) Response of adipose tissue lipoprotein lipase activity and serum lipoproteins to acute hyperinsulinaemia in man. Diabetologia 27:364-369

70. Albalat A, Saera-Vila A, Capilla E, Gutierrez J, Perez-Sanchez J, Navarro I (2007) Insulin regulation of lipoprotein lipase (LPL) activity and expression in gilthead sea bream (Sparus aurata). Comp Biochem Physiol B Biochem Mol Biol 148:151-159

71. Kraemer FB, Takeda D, Natu V, Sztalryd C (1998) Insulin regulates lipoprotein lipase activity in rat adipose cells via wortmannin- and rapamycin-sensitive pathways. Metabolism 47:555-559

72. Wu Q, Ortegon AM, Tsang B, Doege H, Feingold KR, Stahl A (2006) FATP1 is an insulin-sensitive fatty acid transporter involved in diet-induced obesity. Mol Cell Biol 26:34553467

73. Stahl A, Evans JG, Pattel S, Hirsch D, Lodish HF (2002) Insulin causes fatty acid transport protein translocation and enhanced fatty acid uptake in adipocytes. Dev Cell 2:477-488

74. Daval M, Diot-Dupuy F, Bazin R et al (2005) Anti-lipolytic action of AMP-activated protein kinase in rodent adipocytes. J Biol Chem 280:25250-25257

75. Orci L, Cook WS, Ravazzola M et al (2004) Rapid transformation of white adipocytes into fat-oxidizing machines. Proc Natl Acad Sci U S A 101:2058-2063

76. Sullivan JE, Brocklehurst KJ, Marley AE, Carey F, Carling D, Beri RK (1994) Inhibition of lipolysis and lipogenesis in isolated rat adipocytes with AICAR, a cell-permeable activator of AMPactivated protein kinase. FEBS Lett 353:33-36

77. Berggreen C, Gormand A, Omar B, Degerman E, Goransson O (2009) Protein kinase B activity is required for the effects of insulin on lipid metabolism in adipocytes. Am J Physiol Endocrinol Metab 296:E635-E646

78. Jayakumar A, Tai MH, Huang WY et al (1995) Human fatty acid synthase: properties and molecular cloning. Proc Natl Acad Sci U S A 92:8695-8699
79. Smith S, Witkowski A, Joshi AK (2003) Structural and functional organization of the animal fatty acid synthase. Prog Lipid Res 42:289-317

80. An Z, Wang H, Song P, Zhang M, Geng X, Zou MH (2007) Nicotine-induced activation of AMP-activated protein kinase inhibits fatty acid synthase in 3T3L1 adipocytes: a role for oxidant stress. J Biol Chem 282:26793-26801

81. Wolins NE, Skinner JR, Schoenfish MJ, Tzekov A, Bensch KG, Bickel PE (2003) Adipocyte protein S3-12 coats nascent lipid droplets. J Biol Chem 278:37713-37721

82. Ariotti N, Murphy S, Hamilton NA et al (2012) Postlipolytic insulin-dependent remodeling of micro lipid droplets in adipocytes. Mol Biol Cell 23:1826-1837

83. Assimacopoulos-Jeannet F, Brichard S, Rencurel F, Cusin I, Jeanrenaud B (1995) In vivo effects of hyperinsulinemia on lipogenic enzymes and glucose transporter expression in rat liver and adipose tissues. Metabolism 44:228-233

84. Griffin MJ, Wong RH, Pandya N, Sul HS (2007) Direct interaction between USF and SREBP-1c mediates synergistic activation of the fatty-acid synthase promoter. J Biol Chem 282:54535467

85. Kim JB, Sarraf P, Wright M et al (1998) Nutritional and insulin regulation of fatty acid synthetase and leptin gene expression through ADD1/SREBP1. J Clin Invest 101:1-9

86. Sul HS, Latasa MJ, Moon Y, Kim KH (2000) Regulation of the fatty acid synthase promoter by insulin. J Nutr 130:315S-320S

87. Kim JB, Spiegelman BM (1996) ADD1/SREBP1 promotes adipocyte differentiation and gene expression linked to fatty acid metabolism. Genes Dev 10:1096-1107

88. Shimomura I, Shimano H, Korn BS, Bashmakov Y, Horton JD (1998) Nuclear sterol regulatory element-binding proteins activate genes responsible for the entire program of unsaturated fatty acid biosynthesis in transgenic mouse liver. J Biol Chem 273:35299-35306

89. Wang X, Sato R, Brown MS, Hua X, Goldstein JL (1994) SREBP-1, a membrane-bound transcription factor released by sterol-regulated proteolysis. Cell 77:53-62

90. Yabe D, Komuro R, Liang G, Goldstein JL, Brown MS (2003) Liver-specific mRNA for Insig-2 down-regulated by insulin: implications for fatty acid synthesis. Proc Natl Acad Sci U S A 100:3155-3160

91. Amemiya-Kudo M, Shimano H, Yoshikawa T et al (2000) Promoter analysis of the mouse sterol regulatory element-binding protein-1c gene. J Biol Chem 275:31078-31085

92. Im SS, Kwon SK, Kang SY et al (2006) Regulation of GLUT4 gene expression by SREBP-1c in adipocytes. Biochem J 399:131-139

93. Tabor DE, Kim JB, Spiegelman BM, Edwards PA (1999) Identification of conserved cis-elements and transcription factors required for sterol-regulated transcription of stearoyl-CoA desaturase 1 and 2. J Biol Chem 274:20603-20610

94. Shimano H, Horton JD, Shimomura I, Hammer RE, Brown MS, Goldstein JL (1997) Isoform 1c of sterol regulatory element binding protein is less active than isoform 1a in livers of transgenic mice and in cultured cells. J Clin Invest 99:846-854

95. Shimano H, Shimomura I, Hammer RE et al (1997) Elevated levels of SREBP-2 and cholesterol synthesis in livers of mice homozygous for a targeted disruption of the SREBP-1 gene. J Clin Invest 100:2115-2124

96. Taniguchi CM, Kondo T, Sajan M et al (2006) Divergent regulation of hepatic glucose and lipid metabolism by phosphoinositide 3-kinase via Akt and PKClambda/zeta. Cell Metab 3:343-353

97. Matsumoto M, Ogawa W, Akimoto K et al (2003) PKClambda in liver mediates insulin-induced SREBP-1c expression and determines both hepatic lipid content and overall insulin sensitivity. J Clin Invest 112:935-944 
98. Peterson TR, Sengupta SS, Harris TE et al (2011) mTOR complex 1 regulates lipin 1 localization to control the SREBP pathway. Cell 146:408-420

99. Quinn WJ 3rd, Birnbaum MJ (2012) Distinct mTORC1 pathways for transcription and cleavage of SREBP-1c. Proc Natl Acad Sci U S A 109:15974-15975

100. Yecies JL, Zhang HH, Menon S et al (2011) Akt stimulates hepatic SREBP1c and lipogenesis through parallel mTORC1dependent and independent pathways. Cell Metab 14:21-32

101. Bae EJ, Xu J, da Oh Y et al (2012) Liver-specific p70 S6 kinase depletion protects against hepatic steatosis and systemic insulin resistance. J Biol Chem 287:18769-18780

102. Li S, Ogawa W, Emi A et al (2011) Role of S6K1 in regulation of SREBP1c expression in the liver. Biochem Biophys Res Commun 412:197-202

103. Goldstein JL, DeBose-Boyd RA, Brown MS (2006) Protein sensors for membrane sterols. Cell 124:35-46

104. Kotzka J, Knebel B, Haas J et al (2012) Preventing phosphorylation of sterol regulatory element-binding protein 1a by MAPkinases protects mice from fatty liver and visceral obesity. PLoS One 7:e32609

105. Roth G, Kotzka J, Kremer L et al (2000) MAP kinases Erk1/2 phosphorylate sterol regulatory element-binding protein (SREBP)$1 \mathrm{a}$ at serine 117 in vitro. J Biol Chem 275:33302-33307

106. Casado M, Vallet VS, Kahn A, Vaulont S (1999) Essential role in vivo of upstream stimulatory factors for a normal dietary response of the fatty acid synthase gene in the liver. J Biol Chem 274:2009-2013

107. Brady MJ, Saltiel AR (2001) The role of protein phosphatase-1 in insulin action. Recent Prog Horm Res 56:157-173

108. Wong RH, Chang I, Hudak CS, Hyun S, Kwan HY, Sul HS (2009) A role of DNA-PK for the metabolic gene regulation in response to insulin. Cell 136:1056-1072

109. Iizuka K, Bruick RK, Liang G, Horton JD, Uyeda K (2004) Deficiency of carbohydrate response element-binding protein (ChREBP) reduces lipogenesis as well as glycolysis. Proc Natl Acad Sci U S A 101:7281-7286

110. Ma L, Robinson LN, Towle HC (2006) ChREBP*Mlx is the principal mediator of glucose-induced gene expression in the liver. J Biol Chem 281:28721-28730

111. Stoeckman AK, Ma L, Towle HC (2004) Mlx is the functional heteromeric partner of the carbohydrate response element-binding protein in glucose regulation of lipogenic enzyme genes. J Biol Chem 279:15662-15669

112. Yamashita H, Takenoshita M, Sakurai M et al (2001) A glucoseresponsive transcription factor that regulates carbohydrate metabolism in the liver. Proc Natl Acad Sci U S A 98:9116-9121

113. Kawaguchi T, Osatomi K, Yamashita H, Kabashima T, Uyeda K (2002) Mechanism for fatty acid 'sparing' effect on glucoseinduced transcription: regulation of carbohydrate-responsive element-binding protein by AMP-activated protein kinase. J Biol Chem 277:3829-3835

114. Dentin R, Tomas-Cobos L, Foufelle F et al (2012) Glucose 6phosphate, rather than xylulose 5-phosphate, is required for the activation of ChREBP in response to glucose in the liver. J Hepatol 56:199-209

115. Cao H, Gerhold K, Mayers JR, Wiest MM, Watkins SM, Hotamisligil GS (2008) Identification of a lipokine, a lipid hormone linking adipose tissue to systemic metabolism. Cell 134:933-944

116. Bluher M, Michael MD, Peroni OD et al (2002) Adipose tissue selective insulin receptor knockout protects against obesity and obesity-related glucose intolerance. Dev Cell 3:25-38

117. Boucher J, Mori MA, Lee KY et al (2012) Impaired thermogenesis and adipose tissue development in mice with fat-specific disruption of insulin and IGF-1 signalling. Nat Commun 3:902
118. Elgazar-Carmon V, Rudich A, Hadad N, Levy R (2008) Neutrophils transiently infiltrate intra-abdominal fat early in the course of high-fat feeding. J Lipid Res 49:1894-1903

119. Liu J, Divoux A, Sun J et al (2009) Genetic deficiency and pharmacological stabilization of mast cells reduce diet-induced obesity and diabetes in mice. Nat Med 15:940-945

120. Weisberg SP, McCann D, Desai M, Rosenbaum M, Leibel RL, Ferrante AW Jr (2003) Obesity is associated with macrophage accumulation in adipose tissue. J Clin Invest 112:1796-1808

121. Winer DA, Winer S, Shen L et al (2011) B cells promote insulin resistance through modulation of $\mathrm{T}$ cells and production of pathogenic IgG antibodies. Nat Med 17:610-617

122. Wu D, Molofsky AB, Liang HE et al (2011) Eosinophils sustain adipose alternatively activated macrophages associated with glucose homeostasis. Science 332:243-247

123. Wu L, Parekh VV, Gabriel CL et al (2012) Activation of invariant natural killer $\mathrm{T}$ cells by lipid excess promotes tissue inflammation, insulin resistance, and hepatic steatosis in obese mice. Proc Natl Acad Sci U S A 109:E1143-E1152

124. Fain JN, Madan AK, Hiler ML, Cheema P, Bahouth SW (2004) Comparison of the release of adipokines by adipose tissue, adipose tissue matrix, and adipocytes from visceral and subcutaneous abdominal adipose tissues of obese humans. Endocrinology 145:2273-2282

125. Lumeng CN, Deyoung SM, Saltiel AR (2007) Macrophages block insulin action in adipocytes by altering expression of signaling and glucose transport proteins. Am J Physiol Endocrinol Metab 292:E166-E174

126. Suganami T, Tanimoto-Koyama K, Nishida J et al (2007) Role of the Toll-like receptor 4/NF-kappaB pathway in saturated fatty acid-induced inflammatory changes in the interaction between adipocytes and macrophages. Arterioscler Thromb Vasc Biol 27:84-91

127. Kosteli A, Sugaru E, Haemmerle G et al (2010) Weight loss and lipolysis promote a dynamic immune response in murine adipose tissue. J Clin Invest 120:3466-3479

128. Lumeng CN, Bodzin JL, Saltiel AR (2007) Obesity induces a phenotypic switch in adipose tissue macrophage polarization. J Clin Invest 117:175-184

129. Prieur X, Mok CY, Velagapudi VR et al (2011) Differential lipid partitioning between adipocytes and tissue macrophages modulates macrophage lipotoxicity and M2/M1 polarization in obese mice. Diabetes 60:797-809

130. Suganami T, Nishida J, Ogawa Y (2005) A paracrine loop between adipocytes and macrophages aggravates inflammatory changes: role of free fatty acids and tumor necrosis factor alpha. Arterioscler Thromb Vasc Biol 25:2062-2068

131. Winer S, Chan Y, Paltser G et al (2009) Normalization of obesityassociated insulin resistance through immunotherapy. Nat Med 15:921-929

132. Wu H, Ghosh S, Perrard XD et al (2007) T cell accumulation and regulated on activation, normal $\mathrm{T}$ cell expressed and secreted upregulation in adipose tissue in obesity. Circulation 115:1029-1038

133. Deiuliis J, Shah Z, Shah N et al (2011) Visceral adipose inflammation in obesity is associated with critical alterations in tregulatory cell numbers. PLoS One 6:e16376

134. Duffaut C, Zakaroff-Girard A, Bourlier V et al (2009) Interplay between human adipocytes and T lymphocytes in obesity: CCL20 as an adipochemokine and $\mathrm{T}$ lymphocytes as lipogenic modulators. Arterioscler Thromb Vasc Biol 29:1608-1614

135. Feuerer M, Herrero L, Cipolletta D et al (2009) Lean, but not obese, fat is enriched for a unique population of regulatory $\mathrm{T}$ cells that affect metabolic parameters. Nat Med 15:930-939

136. Nishimura S, Manabe I, Nagasaki M et al (2009) $\mathrm{CD} 8^{+}$effector $\mathrm{T}$ cells contribute to macrophage recruitment and adipose tissue inflammation in obesity. Nat Med 15:914-920 
137. Winer S, Paltser G, Chan Y et al (2009) Obesity predisposes to Th17 bias. Eur J Immunol 39:2629-2635

138. Jagannathan-Bogdan M, McDonnell ME, Shin H et al (2011) Elevated proinflammatory cytokine production by a skewed $\mathrm{T}$ cell compartment requires monocytes and promotes inflammation in type 2 diabetes. J Immunol 186:1162-1172

139. Zuniga LA, Shen WJ, Joyce-Shaikh B et al (2010) IL-17 regulates adipogenesis, glucose homeostasis, and obesity. J Immunol 185:6947-6959

140. Ohmura K, Ishimori N, Ohmura $\mathrm{Y}$ et al (2010) Natural killer T cells are involved in adipose tissues inflammation and glucose intolerance in diet-induced obese mice. Arterioscler Thromb Vasc Biol 30:193-199

141. Tabas I, Tall A, Accili D (2010) The impact of macrophage insulin resistance on advanced atherosclerotic plaque progression. Circ Res 106:58-67

142. Mauer J, Chaurasia B, Plum L et al (2010) Myeloid cell-restricted insulin receptor deficiency protects against obesity-induced inflammation and systemic insulin resistance. PLoS Genet 6: e1000938

143. Baumgartl J, Baudler S, Scherner M et al (2006) Myeloid lineage cell-restricted insulin resistance protects apolipoproteinEdeficient mice against atherosclerosis. Cell Metab 3:247-256

144. Uysal KT, Wiesbrock SM, Marino MW, Hotamisligil GS (1997) Protection from obesity-induced insulin resistance in mice lacking TNF-alpha function. Nature 389:610-614

145. Ji C, Chen X, Gao C et al (2011) IL-6 induces lipolysis and mitochondrial dysfunction, but does not affect insulin-mediated glucose transport in 3T3-L1 adipocytes. J Bioenerg Biomembr 43:367-375

146. Lang CH, Dobrescu C, Bagby GJ (1992) Tumor necrosis factor impairs insulin action on peripheral glucose disposal and hepatic glucose output. Endocrinology 130:43-52

147. Rask-Madsen C, Dominguez H, Ihlemann N, Hermann T, Kober L, Torp-Pedersen C (2003) Tumor necrosis factor-alpha inhibits insulin's stimulating effect on glucose uptake and endotheliumdependent vasodilation in humans. Circulation 108:1815-1821

148. Xu H, Hirosumi J, Uysal KT, Guler AD, Hotamisligil GS (2002) Exclusive action of transmembrane TNF alpha in adipose tissue leads to reduced adipose mass and local but not systemic insulin resistance. Endocrinology 143:1502-1511

149. McGillicuddy FC, Chiquoine EH, Hinkle CC et al (2009) Interferon gamma attenuates insulin signaling, lipid storage, and differentiation in human adipocytes via activation of the JAK/ STAT pathway. J Biol Chem 284:31936-31944

150. Rocha VZ, Folco EJ, Sukhova G et al (2008) Interferon-gamma, a Th1 cytokine, regulates fat inflammation: a role for adaptive immunity in obesity. Circ Res 103:467-476

151. Chakrabarti SK, Cole BK, Wen Y, Keller SR, Nadler JL (2009) 12/15-Lipoxygenase products induce inflammation and impair insulin signaling in 3T3-L1 adipocytes. Obesity (Silver Spring) 17:1657-1663

152. Horrillo R, Gonzalez-Periz A, Martinez-Clemente M et al (2010) 5-Lipoxygenase activating protein signals adipose tissue inflammation and lipid dysfunction in experimental obesity. J Immunol 184:3978-3987

153. Lucas S, Taront S, Magnan $C$ et al (2012) Interleukin-7 regulates adipose tissue mass and insulin sensitivity in high-fat diet-fed mice through lymphocyte-dependent and independent mechanisms. PLoS One 7:e40351

154. Miller AM, Asquith DL, Hueber AJ et al (2010) Interleukin-33 induces protective effects in adipose tissue inflammation during obesity in mice. Circ Res 107:650-658

155. Chavey C, Lazennec G, Lagarrigue S et al (2009) CXC ligand 5 is an adipose-tissue derived factor that links obesity to insulin resistance. Cell Metab 9:339-349
156. Ricardo-Gonzalez RR, Red Eagle A, Odegaard JI et al (2010) IL4/STAT6 immune axis regulates peripheral nutrient metabolism and insulin sensitivity. Proc Natl Acad Sci U S A 107:2261722622

157. Levings MK, Schrader JW (1999) IL-4 inhibits the production of TNF-alpha and IL-12 by STAT6-dependent and -independent mechanisms. J Immunol 162:5224-5229

158. Smallie T, Ricchetti G, Horwood NJ, Feldmann M, Clark AR, Williams LM (2010) IL-10 inhibits transcription elongation of the human TNF gene in primary macrophages. J Exp Med 207:20812088

159. Hong EG, Ko HJ, Cho YR et al (2009) Interleukin-10 prevents diet-induced insulin resistance by attenuating macrophage and cytokine response in skeletal muscle. Diabetes 58:2525-2535

160. Chang YH, Ho KT, Lu SH, Huang CN, Shiau MY (2012) Regulation of glucose/lipid metabolism and insulin sensitivity by interleukin-4. Int J Obes (Lond) 36:993-998

161. Olefsky JM (1976) Decreased insulin binding to adipocytes and circulating monocytes from obese subjects. J Clin Invest 57:1165-1172

162. Olefsky JM, Reaven GM (1975) Effects of age and obesity on insulin binding to isolated adipocytes. Endocrinology 96:14861498

163. Grako KA, Olefsky JM, McClain DA (1992) Tyrosine kinasedefective insulin receptors undergo decreased endocytosis but do not affect internalization of normal endogenous insulin receptors. Endocrinology 130:3441-3452

164. Garvey WT, Olefsky JM, Marshall S (1985) Insulin receptor down-regulation is linked to an insulin-induced postreceptor defect in the glucose transport system in rat adipocytes. J Clin Invest 76:22-30

165. Shanik MH, Xu Y, Skrha J, Dankner R, Zick Y, Roth J (2008) Insulin resistance and hyperinsulinemia: is hyperinsulinemia the cart or the horse? Diabetes Care 31(Suppl 2):S262-S268

166. Czech MP (1976) Cellular basis of insulin insensitivity in large rat adipocytes. J Clin Invest 57:1523-1532

167. Carvalho E, Rondinone C, Smith U (2000) Insulin resistance in fat cells from obese Zucker rats - evidence for an impaired activation and translocation of protein kinase $\mathrm{B}$ and glucose transporter 4. Mol Cell Biochem 206:7-16

168. Shao J, Yamashita H, Qiao L, Friedman JE (2000) Decreased Akt kinase activity and insulin resistance in C57BL/KsJ-Leprdb/db mice. J Endocrinol 167:107-115

169. Freidenberg GR, Henry RR, Klein HH, Reichart DR, Olefsky JM (1987) Decreased kinase activity of insulin receptors from adipocytes of non-insulin-dependent diabetic subjects. J Clin Invest 79:240-250

170. Carvalho E, Eliasson B, Wesslau C, Smith U (2000) Impaired phosphorylation and insulin-stimulated translocation to the plasma membrane of protein kinase B/Akt in adipocytes from type II diabetic subjects. Diabetologia 43:1107-1115

171. Cleveland-Donovan K, Maile LA, Tsiaras WG, Tchkonia T, Kirkland JL, Boney CM (2010) IGF-I activation of the AKT pathway is impaired in visceral but not subcutaneous preadipocytes from obese subjects. Endocrinology 151:37523763

172. Um SH, Frigerio F, Watanabe M et al (2004) Absence of S6K1 protects against age- and diet-induced obesity while enhancing insulin sensitivity. Nature 431:200-205

173. Dibble CC, Asara JM, Manning BD (2009) Characterization of Rictor phosphorylation sites reveals direct regulation of mTOR complex 2 by S6K1. Mol Cell Biol 29:5657-5670

174. Ishibashi KI, Imamura T, Sharma PM, Huang J, Ugi S, Olefsky JM (2001) Chronic endothelin-1 treatment leads to heterologous desensitization of insulin signaling in 3T3-L1 adipocytes. J Clin Invest 107:1193-1202 
175. Usui I, Imamura T, Babendure JL et al (2005) G protein-coupled receptor kinase 2 mediates endothelin-1-induced insulin resistance via the inhibition of both Galphaq/11 and insulin receptor substrate-1 pathways in 3T3-L1 adipocytes. Mol Endocrinol 19:2760-2768

176. Kreier F, Fliers E, Voshol PJ et al (2002) Selective parasympathetic innervation of subcutaneous and intra-abdominal fatfunctional implications. J Clin Invest 110:1243-1250

177. Zvonic S, Cornelius P, Stewart WC, Mynatt RL, Stephens JM (2003) The regulation and activation of ciliary neurotrophic factor signaling proteins in adipocytes. J Biol Chem 278:2228-2235

178. Scherer T, O'Hare J, Diggs-Andrews K et al (2011) Brain insulin controls adipose tissue lipolysis and lipogenesis. Cell Metab 13:183-194

179. Ajuwon KM, Spurlock ME (2005) Palmitate activates the NFkappaB transcription factor and induces IL-6 and TNF alpha expression in 3T3-L1 adipocytes. J Nutr 135:1841-1846

180. Hunnicutt JW, Hardy RW, Williford J, McDonald JM (1994) Saturated fatty acid-induced insulin resistance in rat adipocytes. Diabetes 43:540-545

181. Dandona P, Aljada A, Mohanty P et al (2001) Insulin inhibits intranuclear nuclear factor kappaB and stimulates IkappaB in mononuclear cells in obese subjects: evidence for an antiinflammatory effect? J Clin Endocrinol Metab 86:3257-3265

182. Dandona P, Chaudhuri A, Mohanty P, Ghanim H (2007) Antiinflammatory effects of insulin. Curr Opin Clin Nutr Metab Care 10:511-517

183. Viardot A, Grey ST, Mackay F, Chisholm D (2007) Potential antiinflammatory role of insulin via the preferential polarization of effector T cells toward a T helper 2 phenotype. Endocrinology 148:346-353

184. Ghanim H, Korzeniewski K, Sia CL et al (2010) Suppressive effect of insulin infusion on chemokines and chemokine receptors. Diabetes Care 33:1103-1108

185. Iida KT, Shimano H, Kawakami Y et al (2001) Insulin upregulates tumor necrosis factor-alpha production in macrophages through an extracellular-regulated kinase-dependent pathway. J Biol Chem 276:32531-32537

186. McTernan PG, Harte AL, Anderson LA et al (2002) Insulin and rosiglitazone regulation of lipolysis and lipogenesis in human adipose tissue in vitro. Diabetes 51:1493-1498

187. Soop M, Duxbury H, Agwunobi AO et al (2002) Euglycemic hyperinsulinemia augments the cytokine and endocrine responses to endotoxin in humans. Am J Physiol Endocrinol Metab 282: E1276-E1285

188. Siklova-Vitkova M, Polak J, Klimcakova E et al (2009) Effect of hyperinsulinemia and very-low-calorie diet on interstitial cytokine levels in subcutaneous adipose tissue of obese women. Am J Physiol Endocrinol Metab 297:E1154-E1161

189. Odegaard JI, Chawla A (2008) Mechanisms of macrophage activation in obesity-induced insulin resistance. Nat Clin Pract Endocrinol Metab 4:619-626

190. Osborn O, Olefsky JM (2012) The cellular and signaling networks linking the immune system and metabolism in disease. Nat Med 18:363-374

191. Ye J (2008) Regulation of PPARgamma function by TNF-alpha. Biochem Biophys Res Commun 374:405-408

192. Czech MP (1976) Regulation of the D-glucose transport system in isolated fat cells. Mol Cell Biochem 11:51-63

193. Hoehn KL, Turner N, Cooney GJ, James DE (2012) Phenotypic discrepancies in acetyl-CoA carboxylase 2-deficient mice. J Biol Chem 287:15801, Author reply, 287:15802

194. Shirakami A, Toyonaga T, Tsuruzoe K et al (2002) Heterozygous knockout of the IRS-1 gene in mice enhances obesity-linked insulin resistance: a possible model for the development of type 2 diabetes. J Endocrinol 174:309-319
195. Cleasby ME, Reinten TA, Cooney GJ, James DE, Kraegen EW (2007) Functional studies of Akt isoform specificity in skeletal muscle in vivo; maintained insulin sensitivity despite reduced insulin receptor substrate-1 expression. Mol Endocrinol 21:215-228

196. Diraison F, Dusserre E, Vidal H, Sothier M, Beylot M (2002) Increased hepatic lipogenesis but decreased expression of lipogenic gene in adipose tissue in human obesity. Am J Physiol Endocrinol Metab 282:E46-E51

197. Ortega FJ, Mayas D, Moreno-Navarrete JM et al (2010) The gene expression of the main lipogenic enzymes is downregulated in visceral adipose tissue of obese subjects. Obesity (Silver Spring) 18:13-20

198. Lan H, Rabaglia ME, Stoehr JP et al (2003) Gene expression profiles of nondiabetic and diabetic obese mice suggest a role of hepatic lipogenic capacity in diabetes susceptibility. Diabetes 52:688-700

199. Nadler ST, Stoehr JP, Schueler KL, Tanimoto G, Yandell BS, Attie AD (2000) The expression of adipogenic genes is decreased in obesity and diabetes mellitus. Proc Natl Acad Sci U S A 97:11371-11376

200. Kolehmainen M, Vidal H, Alhava E, Uusitupa MI (2001) Sterol regulatory element binding protein 1c (SREBP-1c) expression in human obesity. Obes Res 9:706-712

201. Ducluzeau PH, Perretti N, Laville M et al (2001) Regulation by insulin of gene expression in human skeletal muscle and adipose tissue. Evidence for specific defects in type 2 diabetes. Diabetes 50:1134-1142

202. Sewter C, Berger D, Considine RV et al (2002) Human obesity and type 2 diabetes are associated with alterations in SREBP1 isoform expression that are reproduced ex vivo by tumor necrosis factor-alpha. Diabetes 51:1035-1041

203. Clementi AH, Gaudy AM, van Rooijen N, Pierce RH, Mooney RA (2009) Loss of Kupffer cells in diet-induced obesity is associated with increased hepatic steatosis, STAT3 signaling, and further decreases in insulin signaling. Biochim Biophys Acta 1792:1062-1072

204. Cai D, Yuan M, Frantz DF et al (2005) Local and systemic insulin resistance resulting from hepatic activation of IKK-beta and NFkappaB. Nat Med 11:183-190

205. Roche HM, Noone E, Sewter C et al (2002) Isomer-dependent metabolic effects of conjugated linoleic acid: insights from molecular markers sterol regulatory element-binding protein- $1 \mathrm{c}$ and LXRalpha. Diabetes 51:2037-2044

206. Endo M, Masaki T, Seike M, Yoshimatsu H (2007) TNF-alpha induces hepatic steatosis in mice by enhancing gene expression of sterol regulatory element binding protein-1c (SREBP-1c). Exp Biol Med (Maywood) 232:614-621

207. Lawler JF Jr, Yin M, Diehl AM, Roberts E, Chatterjee S (1998) Tumor necrosis factor-alpha stimulates the maturation of sterol regulatory element binding protein-1 in human hepatocytes through the action of neutral sphingomyelinase. J Biol Chem 273:5053-5059

208. Zhang B, Berger J, Hu E et al (1996) Negative regulation of peroxisome proliferator-activated receptor-gamma gene expression contributes to the antiadipogenic effects of tumor necrosis factor-alpha. Mol Endocrinol 10:1457-1466

209. Xing H, Northrop JP, Grove JR, Kilpatrick KE, Su JL, Ringold GM (1997) TNF alpha-mediated inhibition and reversal of adipocyte differentiation is accompanied by suppressed expression of PPARgamma without effects on Pref-1 expression. Endocrinology 138:2776-2783

210. Suzawa M, Takada I, Yanagisawa J et al (2003) Cytokines suppress adipogenesis and PPAR-gamma function through the TAK1/TAB1/NIK cascade. Nat Cell Biol 5:224-230

211. Festuccia WT, Blanchard PG, Turcotte V et al (2009) Depotspecific effects of the PPARgamma agonist rosiglitazone on 
adipose tissue glucose uptake and metabolism. J Lipid Res 50:1185-1194

212. Festuccia WT, Blanchard PG, Turcotte V et al (2009) The PPARgamma agonist rosiglitazone enhances rat brown adipose tissue lipogenesis from glucose without altering glucose uptake. Am J Physiol Regul Integr Comp Physiol 296:R1327-R1335

213. Laplante M, Sell H, MacNaul KL, Richard D, Berger JP, Deshaies Y (2003) PPAR-gamma activation mediates adipose depot-specific effects on gene expression and lipoprotein lipase activity: mechanisms for modulation of postprandial lipemia and differential adipose accretion. Diabetes 52:291-299

214. Bickel PE, Tansey JT, Welte MA (2009) PAT proteins, an ancient family of lipid droplet proteins that regulate cellular lipid stores. Biochim Biophys Acta 1791:419-440

215. Dalen KT, Schoonjans K, Ulven SM et al (2004) Adipose tissue expression of the lipid droplet-associating proteins S3-12 and perilipin is controlled by peroxisome proliferator-activated receptor-gamma. Diabetes 53:1243-1252

216. Wolins NE, Quaynor BK, Skinner JR et al (2006) OXPAT/PAT-1 is a PPAR-induced lipid droplet protein that promotes fatty acid utilization. Diabetes 55:3418-3428

217. Su D, Coudriet GM, Hyun Kim D et al (2009) FoxO1 links insulin resistance to proinflammatory cytokine IL-1beta production in macrophages. Diabetes 58:2624-2633

218. Goldfine AB, Fonseca V, Jablonski KA, Pyle L, Staten MA, Shoelson SE (2010) The effects of salsalate on glycemic control in patients with type 2 diabetes: a randomized trial. Ann Intern Med 152:346-357

219. Larsen CM, Faulenbach M, Vaag A et al (2007) Interleukin-1 receptor antagonist-treatment of patients with type 2 diabetes. Ugeskr Laeger 169:3868-3871 [article in Danish]

220. Stanley TL, Zanni MV, Johnsen S et al (2011) TNF-alpha antagonism with etanercept decreases glucose and increases the proportion of high molecular weight adiponectin in obese subjects with features of the metabolic syndrome. J Clin Endocrinol Metab 96:E146-E150

221. Letexier D, Peroni O, Pinteur C, Beylot M (2005) In vivo expression of carbohydrate responsive element binding protein in lean and obese rats. Diabetes Metab 31:558-566

222. He Z, Jiang T, Wang Z, Levi M, Li J (2004) Modulation of carbohydrate response element-binding protein gene expression in 3T3-L1 adipocytes and rat adipose tissue. Am J Physiol Endocrinol Metab 287:E424-E430

223. Hurtado del Pozo C, Vesperinas-Garcia G, Rubio MA et al (2011) ChREBP expression in the liver, adipose tissue and differentiated preadipocytes in human obesity. Biochim Biophys Acta 1811:1194-1200

224. Koranyi L, James D, Mueckler M, Permutt MA (1990) Glucose transporter levels in spontaneously obese $(\mathrm{db} / \mathrm{db})$ insulin-resistant mice. J Clin Invest 85:962-967

225. Garvey WT, Maianu L, Huecksteadt TP, Birnbaum MJ, Molina JM, Ciaraldi TP (1991) Pretranslational suppression of a glucose transporter protein causes insulin resistance in adipocytes from patients with non-insulin-dependent diabetes mellitus and obesity. J Clin Invest 87:1072-1081

226. Lodhi IJ, Yin L, Jensen-Urstad AP et al (2012) Inhibiting adipose tissue lipogenesis reprograms thermogenesis and PPARgamma activation to decrease diet-induced obesity. Cell Metab 16:189201

227. Liu LH, Wang XK, Hu YD, Kang JL, Wang LL, Li S (2004) Effects of a fatty acid synthase inhibitor on adipocyte differentiation of mouse 3T3-L1 cells. Acta Pharmacol Sin 25:10521057

228. Schmid B, Rippmann JF, Tadayyon M, Hamilton BS (2005) Inhibition of fatty acid synthase prevents preadipocyte differentiation. Biochem Biophys Res Commun 328:1073-1082
229. Jiang G, Dallas-Yang Q, Li Z et al (2002) Potentiation of insulin signaling in tissues of Zucker obese rats after acute and long-term treatment with PPARgamma agonists. Diabetes 51:2412-2419

230. Jiang G, Dallas-Yang Q, Biswas S, Li Z, Zhang BB (2004) Rosiglitazone, an agonist of peroxisome-proliferator-activated receptor gamma (PPARgamma), decreases inhibitory serine phosphorylation of IRS1 in vitro and in vivo. Biochem J 377:339-346

231. Leonardini A, Laviola L, Perrini S, Natalicchio A, Giorgino F (2009) Cross-talk between PPARgamma and insulin signaling and modulation of insulin sensitivity. PPAR Res 2009:818945

232. Yang X, Zhang X, Heckmann BL, Lu X, Liu J (2011) Relative contribution of adipose triglyceride lipase and hormone-sensitive lipase to tumor necrosis factor-alpha (TNF-alpha)-induced lipolysis in adipocytes. J Biol Chem 286:40477-40485

233. Hotamisligil GS, Peraldi P, Budavari A, Ellis R, White MF, Spiegelman BM (1996) IRS-1-mediated inhibition of insulin receptor tyrosine kinase activity in TNF-alpha- and obesityinduced insulin resistance. Science 271:665-668

234. Chen X, Xun K, Chen L, Wang Y (2009) TNF-alpha, a potent lipid metabolism regulator. Cell Biochem Funct 27:407-416

235. Weiner FR, Smith PJ, Wertheimer S, Rubin CS (1991) Regulation of gene expression by insulin and tumor necrosis factor alpha in 3T3-L1 cells. Modulation of the transcription of genes encoding acyl-CoA synthetase and stearoyl-CoA desaturase-1. J Biol Chem 266:23525-23528

236. Delikat SE, Galvani DW, Zuzel M (1995) The metabolic effects of interleukin 1 beta on human bone marrow adipocytes. Cytokine 7:338-343

237. McGillicuddy FC, Harford KA, Reynolds CM et al (2011) Lack of interleukin-1 receptor I (IL-1RI) protects mice from high-fat diet-induced adipose tissue inflammation coincident with improved glucose homeostasis. Diabetes 60:1688-1698

238. de Roos B, Rungapamestry V, Ross K et al (2009) Attenuation of inflammation and cellular stress-related pathways maintains insulin sensitivity in obese type I interleukin-1 receptor knockout mice on a high-fat diet. Proteomics 9:3244-3256

239. Lagathu C, Bastard JP, Auclair M, Maachi M, Capeau J, Caron M (2003) Chronic interleukin-6 (IL-6) treatment increased IL-6 secretion and induced insulin resistance in adipocyte: prevention by rosiglitazone. Biochem Biophys Res Commun 311:372-379

240. Matthews VB, Allen TL, Risis S et al (2010) Interleukin-6deficient mice develop hepatic inflammation and systemic insulin resistance. Diabetologia 53:2431-2441

241. Di Gregorio GB, Hensley L, Lu T, Ranganathan G, Kern PA (2004) Lipid and carbohydrate metabolism in mice with a targeted mutation in the IL-6 gene: absence of development of age-related obesity. Am J Physiol Endocrinol Metab 287:E182E187

242. O'Rourke RW, White AE, Metcalf MD et al (2012) Systemic inflammation and insulin sensitivity in obese IFN-gamma knockout mice. Metabolism 61:1152-1161

243. Kowalski GM, Nicholls HT, Risis S et al (2011) Deficiency of haematopoietic-cell-derived IL-10 does not exacerbate high-fatdiet-induced inflammation or insulin resistance in mice. Diabetologia 54:888-899

244. Perrier S, Darakhshan F, Hajduch E (2006) IL-1 receptor antagonist in metabolic diseases: Dr Jekyll or Mr Hyde? FEBS Lett 580:6289-6294

245. Sauter NS, Schulthess FT, Galasso R, Castellani LW, Maedler K (2008) The antiinflammatory cytokine interleukin-1 receptor antagonist protects from high-fat diet-induced hyperglycemia. Endocrinology 149:2208-2218

246. Somm E, Henrichot E, Pernin A et al (2005) Decreased fat mass in interleukin-1 receptor antagonist-deficient mice: impact on adipogenesis, food intake, and energy expenditure. Diabetes 54:3503-3509 